ZOOLOGIA 27 (5): 761-788, October, 2010

doi: $10.1590 /$ S1984-46702010000500014

\title{
Review and phylogeny of Lutzsimulium (Diptera: Simuliidae)
}

\author{
Leonardo H. Gil-Azevedo
}

Fundação Oswaldo Cruz, Instituto Oswaldo Cruz, Laboratório de Simulídeos e Oncocercose. Avenida Brasil 4365, Manguinhos, Caixa Postal 926, 21045-900 Rio de Janeiro, RJ, Brazil. E-mail: Ihgazevedo@yahoo.com.br

\begin{abstract}
Lutzsimulium d'Andretta Jr \& Vulcano, 1947 is an enigmatic South American genus with four species: $L$. flavopubescens Lutz, 1910, L. hirticosta Lutz, 1909, L. pernigrum Lutz, 1910 and L. simplicicolor Lutz, 1910. It can be diagnosed by median arms of furcasternum with projections; subbasal tooth of the claw reduced; wing basal cell absent; spermatheca with net-like structure; apex of trichomes coiled (pupa); gill with two main trunks (pupa); antennomere 3 equal to or longer than 1+2 (larva); hypostomal teeth reduced (larva); postgenal cleft deep (larva). A morphological cladistic analysis under equal weights, with the four Lutzsimulium species and six outgroups, resulted in two most parsimonious trees, with 81 steps, $\mathrm{Cl}=0.61$ and $\mathrm{RI}=0.68$. The monophyly of the genus is corroborated, supported by 15 synapomorphies, therefore it is proposed that Kempfsimulium Py-Daniel \& Nunes de Mello, 1982 is synonymous of Lutzsimulium. Also the status of Araucnephia Wygodzinsky \& Coscarón, 1973 and Araucnephioides Wygodzinsky \& Coscarón, 1973 are revalidated, because they do not form a monophyletic group with Lutzsimulium. All the species of Lutzsimulium are revised, with redescriptions, illustrations and identification keys for adults, pupa and larva. The male and larva of $L$. flavopubescens are described for the first time.
\end{abstract}

KEY WORDS. Argentina; black-fly; Brazil; cladistics; Culicomorpha; Insecta; Neotropical Region; taxonomy.

In South America, there are approximately 300 valid species of simuliids distributed among nine genera (ADLER \& Crosskey 2009). All of them are classified in Simuliini (GILAzevedo \& Maia-Herzog 2007). Six genera are endemic to the western side of the Andes Mountain Range, and two occur on both sides, but only Lutzsimulium d'Andretta Jr \& Vulcano, 1947 is endemic to the Andean eastern side. There are four valid species of Lutzsimulium. Three are found from northeastern Argentina to the northeastern Brazil, and one is found in the southern and eastern borders of the Brazilian Amazon Forest.

D'Andretta Jr \& Vulcano (1947) established Lutzsimulium for a new puzzling species, L. cruzi d'Andretta Jr \& Vulcano, 1947, which was later synonymized with Simulium hirticosta Lutz, 1909 (Vulcano 1967). In subsequent articles, Vulcano \& D'ANDretta Jr (1952) and Py-Daniel $(1979,1982)$ respectively, added S. pernigrum Lutz, 1910, S. simplicicolor Lutz, 1910, and S. flavopubescens Lutz, 1910. C. D'Andretta Jr and M. Vulcano could not have chosen a better name for the genus, since all the species had been originally described by LuTz $(1909,1910)$.

There are few systematic papers on Lutzsimulium, and fewer still about the ecology and bionomics of the genus. The small number of specimens deposited in collections and the fact that the included species lack medical or economic importance (only L. simplicicolor is recorded as a human biter), might be the reasons for the lack publications on the genus.

In this paper, Lutzsimulium is revised, and the male and larva of $L$. flavopubescens are described for the first time. Iden- tification keys for adults, pupa and larva, and a discussion of the phylogeny of the genus are also included.

\section{MATERIAL AND METHODS}

The specimens of Lutzsimulium studied herein are deposited in the following institutions: Instituto Nacional de Pesquisas da Amazônia (Brazil, INPA); Instituto Oswaldo Cruz, Historic Collection of Adolpho Lutz (Brazil, LUTZ-IOC); Instituto Oswaldo Cruz, Laboratório de Simulídeos e Oncocercose (Brazil, LSO-IOC); Museo de La Plata (Argentina, MLP); Museu de Zoologia da Universidade de São Paulo (Brazil, MZSP); and Universidade de São Paulo, Faculdade de Saúde Pública (Brazil, FSP-USP). The techniques used here were described in GiL-AzEvedo et al. (2005a, b). The morphological terminology generally follows ADLER et al. (2004) with some terms added from WYgodzinsky \& Coscarón (1973) and Gil-Azevedo \& Maia-Herzog (2007).

A cladistic analysis was performed to test the monophyly of Lutzsimulium and to find out how the species of the genus relate to each other. Six putative outgroups were used: Helodon alpestris (Dorogostaisky, Rubtsov \& Vlasenko, 1935); Araucnephia montana (Philippi, 1865); A. iberaensis Coscarón \& CoscarónArias, 2002; Gigantodax brophyi (Edwards, 1931); Paracnephia tonnoiri (Drummond, 1931); Paraustrosimulium anthracinum (Bigot, 1888); Simulium (Chirostilbia) pertinax Kollar, 1832 (Appendix 1). Characters were preferentially coded reductively (WILKINSON 1995) and multistate characters were treated as un- 
ordered (FIтch 1971). When two or more states of a character were found in one terminal taxon, the character was treated as polymorphic and both states were coded in the matrix. For the maximum parsimony analyses under equal weights the program NONA (GolobofF 1993) was used. The searches were carried out through exact algorithms and the sequence of commands was: "hold 100000 search mswap+".

The parsimony analyses including the representatives of the ingroup and outgroup resulted in unrooted networks. Character optimization and mapping, and comparisons among the trees obtained were carried out with the WinClada program (NIXON 2002). Branch support was estimated by bootstrap (FelsensteIn 1985), via WinClada (NIXon 2002), with 3,000 replications. The decay index (BREMER, 1994) of each branch was calculated by Autodecay (ERIKSSON 2001) using PAUP* (SwOFFord 1998).

The matrix proposed by Py-DANIEL (1982: 297) was adapted and a hypothetical ancestor was included to polarize the matrix. The data set was analyzed under the same parameters of my main analysis.

\section{CLADISTIC ANALYSIS}

The data matrix was composed of 11 terminal taxa and 53 characters, obtained from adult (24), pupa (16) and larva of last instar (13) (Appendix 2). The characters used in the present analysis are listed below. The discussion of characters and their consistecy indexes (ci) are given for one of the two shortest trees, chosen to represent the phylogeny of the group (Fig. 1). Character states were mapped on the cladogram using the acelerating transformation optimization criterion (ACCTRAN).

\section{Adult}

1. Clypeus in the female: (0) as wide as long; (1) longer than wide. $\mathrm{ci}=0.25$.

Character 5 of Coscarón \& Miranda-Esquivel (1998: 163); 36 of Pinto-SAnChéz et al. (2005: 21); and 4 of Gil-AzEvedo \& Maia-Herzog (2007: 43). The derived character state (0) is a synapomorphy of $L$. hirticosta $+L$. pernigrum $+L$. flavopubescens, with a reversal to estate (1) in L. pernigrum.

2. Shape of the apex of the clypeus in the female: (0) acute (Figs 3 and 42$) ;(1)$ round. $\mathrm{ci}=1.00$.

Character 5 of Gil-Azevedo \& Maia-Herzog (2007: 43).

3. Clypeus acute apex: (0) small (Fig. 3); (1) distinctly developed (Fig. 42).

State (1) is an autapomorphy of $L$. simplicicolor.

4. Teeth of the mandible in the female: (0) developed on both sides; (1) developed just on the inner side. $\mathrm{ci}=0.50$.

Character 18 of Py-Daniel (1982: 298); 38 of Pinto-Sanchéz et al. (2005: 21); and 7 of Gil-Azevedo \& Maia-Herzog (2007: 43). State (1) is a synapomorphy for Lutzsimulium.

5. Ratio between the length of the last and of the penultimate palpomeres: (0) the last distinctly longer than the penultimate;
(1) the last and the penultimate approximately equal. $\mathrm{ci}=0.50$.

Modified from character 8 of GiL-AzEvedo \& MAIA-Herzog (2007: 43). The derived character state (1) is a synapomorphy for Lutzsimulium, with a reversal to (0) in L. hirticosta.

6. General coloration of the thorax of the female: (0) black; (1) brown and red; (2) yellow and orange. $\mathrm{ci}=0.66$

Character 12 of Gil-Azevedo \& Maia-Herzog (2007: 43). The black thorax is the plesiomorphic state. The brown thorax is an autapomorphy of $L$. hirticosta, and the orange thorax is an autapomorphy of $L$. simplicicolor.

7. Median arms of furcasternum: (0) without projections; (1) with projections (Fig. 5). $\mathrm{ci}=0.50$.

Character 8 of Py-Daniel (1982: 298); 176 of AdLer et al. (2004: 154); and 20 of Gil-Azevedo \& Maia-Herzog (2007: 44). The presence of a projection on the median arms of the furcasternum is a synapomorphy for Lutzsimulium. Py-DanieL (1982) proposed that there are two different types of median arms, large and small, but I could not see a major difference.

8. Length of the subbasal tooth of hind claw of the female: (0) developed, reaching about half the length of the main tooth; (1) reduced, smaller than a third of the main tooth (Fig. 8). $c i=0.50$.

Modified from character 19 of Py-Daniel (1982: 298); 14 of Coscarón \& Miranda-Esquivel (1998: 163); 106 of Adler et al. (2004: 146); 50 of Pinto-SAnchÉz et al. (2005: 22). Character 18 of GILAzevedo \& Maia-Herzog (2007: 44). The reduced subbasal tooth is a synapomorphy of A. iberaensis + Lutzsimulium +Simulium.

9. Chaetotaxy of the vein R1: (0) only hair-like setae; (1) hair-like and spine-like setae. $\mathrm{ci}=0.50$.

Character 10 of Py-Daniel (1982: 298); and 25 of GILAzevedo \& Maia-Herzog (2007: 47).

10. Basal cell (vein m-cu): (0) present; (1) absent (Fig. 6). $\mathrm{ci}=0.50$.

Character 16 of Py-DANiel (1982: 298); 175 of AdLer et al. (2004: 154); and 28 of Gil-Azevedo \& Maia-Herzog (2007: 48). The absence of basal cell is a synapomorphy for Lutzsimulium.

11. Halter apex: (0) dark; (1) light. $\mathrm{ci}=0.50$.

Character 30 of Gil-Azevedo \& Maia-Herzog (2007: 40).

\section{Female Terminalia}

12. Paraproct with a distinctly tail-like expansion: (0) absent (Fig. 45); (1) present (Fig. 10). ci = 1.00.

The tail-like expansion of paraproct is a synapomorphy of L. hirticosta ( $L$. flavopubescens $+L$. pernigrum).

13. Paraproct with a digit-like projection at the anterior and basal portion: (0) absent (Fig. 10); (1) present (Fig. 45).

The digit-like projection of the paraproct is an autapomorphy of $L$. simplicicolor.

14. Ratio between the height and width of the cerci: (0) width more than twice the height; (1) width equal or less than twice of height. $\mathrm{ci}=1.00$.

Character 32 of Gil-Azevedo \& Maia-Herzog (2007: 48). 
15. Spermatheca coloration: (0) surface of spermathecal neck and duct transparent, remaining spermatheca pigmented; (1) spermatheca totally pigmented, duct transparent; (2) spermatheca and duct pigmented. $\mathrm{ci}=0.66$.

Modified from character 21 of Py-Daniel (1982: 298); 1 of EVANS \& AdLer (2000: 1471). Character 38 of GIL-AzEvedo \& MaIAHerzog (2007: 49). The derived character state (2) is a synapomorphy for Lutzsimulium. In the discussion of his character 21, Py-Daniel (1982), suggested that there are small spicules on the internal surface of the spermatheca in Lutzsimulium (except L. simplicicolor). It is however impossible to observe clearly with a light microscope. Therefore the presence/absence of these spicules was not used in this analysis.

16. Spermathecal surface: (0) smooth; (1) with a net-like structure (Figs 12 and 47). $\mathrm{ci}=1.00$.

Character 39 of Gil-Azevedo \& Maia-Herzog (2007: 49). The net-like structure of the spermatheca is a synapomorphy for Lutzsimulium.

17. Spermathecal net-like structure distribution: $(0)$ in the spermathecal neck and duct (Fig. 12); (1) only on the duct (Fig. 47).

Character 40 of Gil-Azevedo \& Maia-Herzog (2007: 49). State (0) is present in $L$. hirticosta ( $L$. flavopubescens $+L$. pernigrum); and state (1) is present in L. simplicicolor. As the net-like structure is absent in the outgroup, this character is uninformative.

\section{Male Terminalia}

18. Length ratio between gonostylus/gonocoxite: (0) gonostylus more than $2 / 3$ of gonocoxite; (1) gonostylus less than $2 / 3$ of gonocoxite (Figs 13, 28, 37 and 48). ci = 0.50.

Character 43 of Gil-Azevedo \& Maia-Herzog (2007: 49). The derived state (1) is a synapomorphy for Lutzsimulium.

19. Ratio between height and width of the gonostylus: $(0)$ the height more than twice the base; (1) height less than twice the width, but distinctly greater (Figs 13, 28, 37 and 48); (2) the height and width with similar lengths. $\mathrm{ci}=0.66$.

Character 45 of Gil-Azevedo \& Maia-Herzog (2007: 49). The derived character state (1) is a synapomorphy of $A$. iberaensis + Lutzsimulium

20. Number of spurs on the gonostylus: (0) 2 ; (1) $3 . \mathrm{ci}=0.50$.

Character 48 of Gil-Azevedo \& MaiA-Herzog (2007: 50). The gonostylus with three spurs is an autapomorphy of $L$. hirticosta. In L. pernigrum both states occur.

21. Ventral plate in dorsal view: (0) medial portion narrower than basal portion (Fig. 15); (1) medial portion wider than basal portion (Fig. 49). $\mathrm{ci}=0.33$.

The derived character state $(0)$ is a synapomorphy of $L$. hirticosta (L. flavopubescens + L. pernigrum).

22. Distal area of median sclerite: (0) without teeth (Fig. 16); (1) with teeth (Fig. 50).

Character 25 of Py-Daniel (1982: 299). The presence of teeth on the distal area of the median sclerite is an autapomorphy of L. simplicicolor.

23. Median sclerite with laterally pointed apex: (0) absent (Fig. 50); (1) present (Fig. 16).

The derived character state (0) is an autapomorphy of $L$. simplicicolor.

24. Endoparamere: (0) present; ( 1 ) reduced or absent. ci $=1.00$.

Character 26 of Py-Daniel (1982: 299), and 52 of GILAzevedo \& Maia-Herzog (2007: 52). The reduced or absent endoparamere is a synapomorphy of L. hirticosta ( $L$. flavopubescens $+L$. pernigrum).

\section{Pupa}

25. Round tubercles on the cephalothorax: (0) present; (1) absent. $\mathrm{ci}=0.33$.

Character 62 of Gil-Azevedo \& Maia-Herzog (2007: 51). The absence of tubercles occurs in $L$. simplicicolor and $L$. pernigrum, independently.

26. Spiniform trichomes on the frontoclipeus: (0) present; (1) absent. $\mathrm{ci}=1.00$.

Character 70 of Gil-Azevedo \& Maia-Herzog (2007: 53).

27. Apex of the facial hair-like trichomes: (0) coiled; (1) straight. $\mathrm{ci}=1.00$.

Modified from character 33 of Py-Daniel (1982: 299). Character 69 of Gil-Azevedo \& MaiA-Herzog (2007: 53). The occurrence of coiled facial trichomes is a synapomorphy of $A$. iberaensis + Lutzsimulium.

28. Sexual dimorphism in the pupal frontal trichomes: (0) absent; (1) present, absent in female and present in male. ci $=1.00$.

The presence of sexual dimorphism in the frontal trichomes is a synapomorphy of L. hirticosta (L. flavopubescens + L. pernigrum).

29. Apex of the hair-like trichomes of the dorsal-scutum region: (0) coiled; (1) straight. $\mathrm{ci}=1.00$.

Character 67 of Gil-Azevedo \& Maia-Herzog (2007: 53). The coiled condition of the dorsal-scutum trichomes is a synapomorphy of $A$. iberaensis + Lutzsimulium.

30. Spiniform trichomes on the dorsal region of the scutum: (0) absent; (1) present. $\mathrm{ci}=0.50$.

Character 65 of Gil-Azevedo \& Maia-Herzog (2007: 51).

31. Number of gill main trunks: (0) three; (1) two (Fig. 17). ci = 1.00.

The presence of two main trunks on the gill is a synapomorphy for Lutzsimulium.

32. Aspect of the abdomen: (0) with most plates sclerotized and bearing tubercles; (1) with only T I-II or T I-III sclerotized and bearing tubercles; (2) not sclerotized, plates membranous and without tubercles.

Modified from character 188 of AdLer et al. (2004: 155), and character 71 of Gil-Azevedo \& Maia-Herzog (2007: 53). This character is uninformative. 
33. Hooks of tergites III-IV: (0) short and robust; (1) long and thin (similar to the ventral hooks). $\mathrm{ci}=1.00$.

Character 73 of Gil-Azevedo \& Maia-Herzog (2007: 53).

34. Shape of the terminal setae: (0) straight; (1) curved; (2) anchorlike.

Modified from character 38 of Py-Daniel (1982: 299), and character 77 of Gil-Azevedo \& Maia-Herzog (2007: 54). This character is uninformative.

35. Terminal spines: (0) reduced or absent; (1) developed. $\mathrm{ci}=1.00$.

Modified from character 37 of Py-Daniel (1982: 299); and character 78 of Gil-Azevedo \& MaiA-Herzog (2007: 54).

36. Ventral hooks on segment IV: (0) absent (Fig. 3B); (1) present (Fig. 52). $\mathrm{ci}=0.50$.

Character 79 of Gil-Azevedo \& Maia-Herzog (2007: 54). The presence of ventral hooks on segment IV is an autapomorphy of L. simplicicolor.

37. Number of hooks on sternite V: (0) 2+2 (Figs 18 and 52); (1) $3+3 . \mathrm{ci}=1.00$.

Character 81 of Gil-Azevedo \& Maia-Herzog (2007: 54).

38. Number of hooks on sternite VI: (0) $1+1$ (Figs 18 and 52); (1) $2+2 . \mathrm{ci}=1.00$.

Character 82 of Gil-Azevedo \& Maia-Herzog (2007: 54).

39. Shape of the cocoon: (0) well-defined and symmetrical; (1) illdefined and asymmetrical (Figs 19, 30, 39 and 53). ci = 1.00.

Character 32 of Py-Daniel (1982: 299), 1 of STUART \& HunTER (1998: 398), 185 of AdLer et al. (2004: 155), and 87 of GIL-AzEVEDO \& Maia-Herzog (2007: 54).

40. Anterior rim of the cocoon: (0) not defined (Figs 19, 30, 39 and 53); (1) defined. $\mathrm{ci}=1.00$.

Character 90 of Gil-Azevedo \& Maia-Herzog (2007: 55).

\section{Larva}

41. Pigmentation of the antenna: (0) all articles equally unpigmented; (1) articles 1 and 2 unpigmented, contrasting with the dark antennomere 3. $\mathrm{ci}=0.50$.

Character 46 of Py-Daniel (1982: 299), 17 of CurRiE \& Grimaldi (2000: 478), 49 and 169 of AdLer et al. (2004: 135, 155), 4 of Pinto-SAnchéz et al. (2005: 19), and 97 of Gil-AzEvedo \& Maia-Herzog (2007: 56). The derived character state (1) is a synapomorphy of $L$. hirticosta (L. flavopubescens + L. pernigrum).

42. Ratio between the length of articles 1 and 2: (0) 1 longer than 2 (Fig. 31); (1) 2 equal to or longer than 1 (Figs 21, 40 and 55). $\mathrm{ci}=0.50$.

Character 40 of Coscarón \& Miranda-EsQUivel (1998: 163); 1 of Pinto-SAnchéz et al. (2005: 19), and 98 of GIL-AzEvedo \& MaiAHerzog (2007: 56). The derived state (0) is an autapomorphy of L. hirticosta.

43. Length of the antennomere 3 : ( 0$)$ shorter than $1+2$; $(1)$ equal to or longer than $1+2$ (Figs 21, 31, 40 and 55). $\mathrm{ci}=0.50$.

Modified for character 2 of Pinto-SAnchéz et al. (2005: 19), and 99 of Gil-Azevedo \& Maia-Herzog (2007: 56). The derived character state (1) is a synapomorphy of A. iberaensis + Lutzsimulium + Paraustrosimulium + Simulium, with a reversal to state (0) in Simulium.

44. Mandibular serrations: (0) more than 7 teeth; (1) from 1 to 6 teeth. $\mathrm{ci}=0.33$.

Character 101 of Gil-Azevedo \& Maia-Herzog (2007: 56). The derived state (1) is a synapomorphy for Lutzsimulium.

45. Hypostomal teeth: (0) developed - distinctly separate from the hypostomal plate; ( 1 ) reduced - next to the hypostomal plate, which partially covers the teeth (Figs 22 and 56). ci $=0.50$.

Modified from character 183 of ADLER et al. (2004: 155), and character 102 of Gil-Azevedo \& MaiA-Herzog (2007: 57). The derived character state (1) is a synapomorphy for Lutzsimulium.

46. Form of paralateral teeth: (0) at least one developed; (1) all reduced (Figs $4 \mathrm{C}$ and $10 \mathrm{~F}$ ). $\mathrm{ci}=0.50$.

The derived state (1) is a synapomorphy for Lutzsimulium.

47. Number of paralateral teeth of the hypostoma: (0) $1+1$ (Fig. 56); (1) 2+2 (Fig. 22); (2) 4+4. ci = 1.00.

Character 105 of Gil-Azevedo \& Maia-Herzog (2007: 58). The hypostoma with $1+1$ paralateral teeth is an autapomorphy of $L$. simplicicolor.

48. Postgenal cleft extended anteriorly, about one third or more its distance to the hypostomal groove: (0) absent, postgenal cleft shallow; (1) present, postgenal cleft deep (Figs 23, 32, 41 and 57$)$. $\mathrm{ci}=0.50$.

Character 184 of AdLer et al. (2004); character 108 of GILAzevedo \& Maia-Herzog (2007). The deep postgenal cleft is a synapomorphy for Lutzsimulium.

49. Shape of deep postgenal cleft: (0) subtriangular; (1) oval (Figs 32 and 57); (2) subsquare (Figs 23 and 41). ci $=1.00$.

Modified from character 109 of Gil-Azevedo \& MaiAHerzog (2007: 58).

The oval postgenal cleft is present in L. simplicicolor and $L$. hirticosta. The derived subsquare postgenal cleft is a synapomorphy of $L$. pernigrum $+L$. flavopubescens.

50. Border of deep postgenal cleft: (0) regular (Figs 32 and 57); (1) irregular (Figs 23 and 41). ci $=1.00$.

The irregular border of deep postgenal cleft is a synapomorphy of $L$. pernigrum $+L$. flavopubescens.

51. Larval body tegument: (0) glabrous; (1) with hairs.

Character 05 of Miranda-Esquivel \& Coscarón (2001). The body tegument with hairs is an autapomorphy of L. hirticosta. Py-Daniel (1982) (character 53, p. 300) described membranous projections on the cuticle. However, I was not able to observe those projections. Also, Py-Daniel (1982) (character 54, p. 300) proposed that there are ventral tubercles in all Lutzsimulium (except $L$. simplicicolor), but I was not able to see those tubercles in any species. 
52. Larval body shape: (0) straight; (1) abdomen club-like, with rounded distal apex. $\mathrm{ci}=1.00$.

Character 206 of AdLer et al. (2004).

53. Ratio between the length of the arms of the anal sclerite: (0) ventral arm distinctly longer than the dorsal one (Fig. 24); (1) ventral and dorsal arms similar in size (Fig. 33). $\mathrm{ci}=0.25$.

Character 114 of Gil-Azevedo \& MaiA-Herzog (2007: 58). The derived character state (1) is an autapomorphy of $L$. hirticosta.

\section{Discussion}

Even though I have tried to use all characters of Py-DANIEL (1982) in my analysis, some characters were found to be inappropriate for cladistics, as follows: 1) character 9 (p. 298): PyDANIEL proposed that $L$. simplicicolor does not have setae on the Sc vein, but a few setae (three) are present on the Sc vein of $L$. simplicicolor; 2) character 15 (p. 298): this character, pertaining the shape of the katepisternum, has several intermediate conditions, making it difficult to distinguish between the states proposed by the author; 3) character 39 (p. 299): the presence of two transversal grooves on the dorsum of the pupal abdomen (present in L. simplicicolor) is a confusion the author made with the sutures between the tergites and pleurites, present in all Simuliidae.

The cladistic analysis under equal weights resulted in two most parsimonious trees with 92 steps, $\mathrm{CI}=0.65$ and $\mathrm{RI}=0.71$. The difference between the two trees pertains the sister group of Lutzsimulium, which can be either Araucnephia iberaensis or Simulium + Paraustrosimulium. The tree that shows A. iberaensis as the sister-group of Lutzsimulium was chosed for character optimization and discussion. This tree (Fig. 1) does not show autapomorphic characters.

The monophyly of Lutzsimulium, including L. simplicicolor (as in Gil-Azevedo \& Maia-Herzog 2007), is corroborated in this analysiswith high support. Thirteen synapomorphies support the genus, six from the adult, one from the pupa, and six from the larva (Fig. 1). The synapomorphies without ambiguous optimization are: teeth of the female mandible developed only on the inner face (character 4, state 1); basal cell (vein m-cu) absent (character 10, state 1); spermatheca and duct pigmented

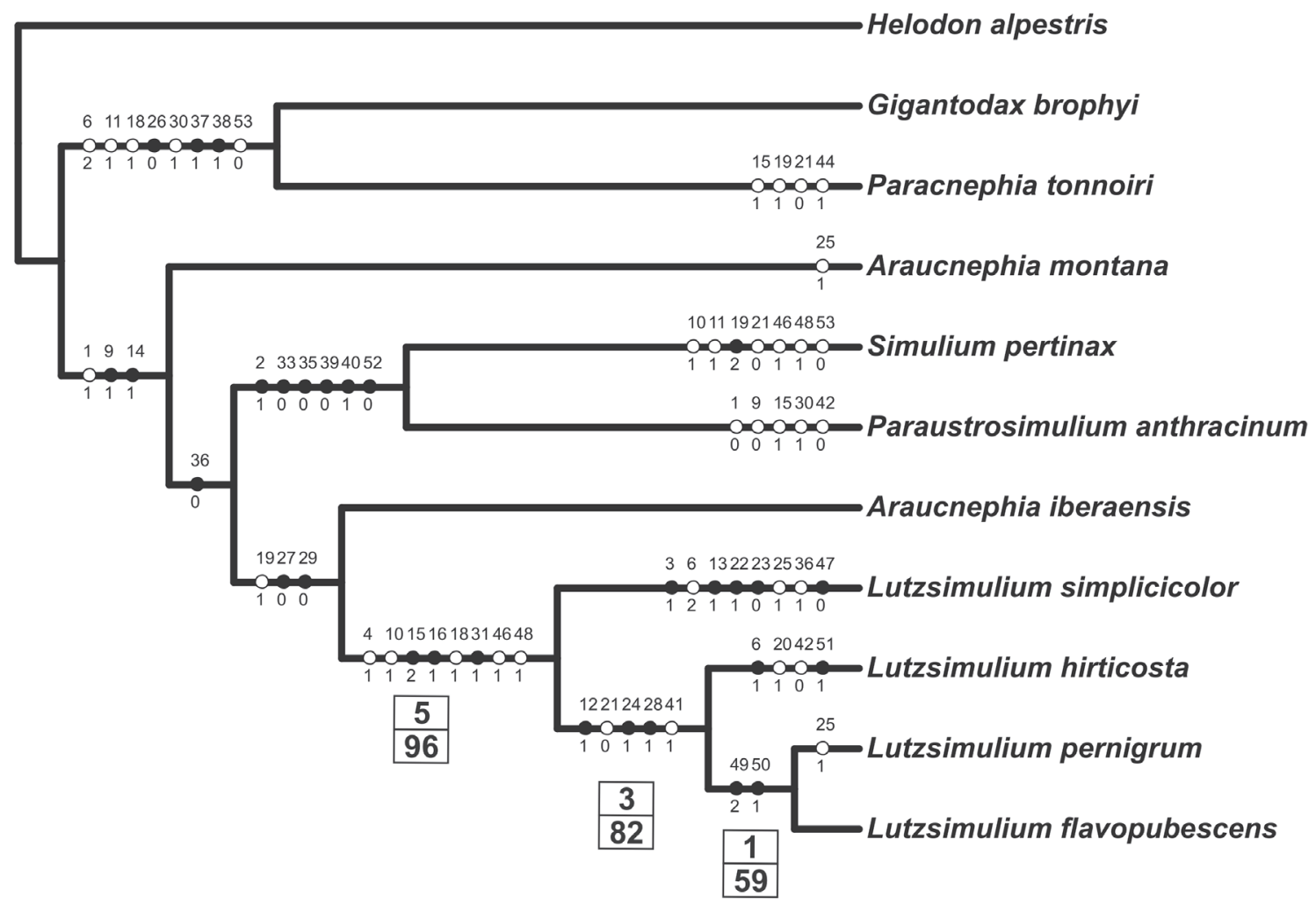

Figure 1. One of two trees obtained with maximum parsimony, unweighted characters, chosen to represent the phylogenetic relationships of the Lutzsimulium (81 steps, consistency index $=0.65$ and retention idex $=0.71$, not considering the autapomorphic characters). Only unambiguous apomorphies are represented in the diagram; circles represents apomorphies (white = homoplastic; black = nonhomoplastic); the numbers above the circles represent characters and the numbers below refer to character states. Branch support in the boxes: decay index (above) and bootstrap (below). 
(character 15, state 2); spermathecal neck surface and duct with a net-like structure (character 16, state 1); male gonostylus less than $2 / 3$ length of the gonocoxite (character 18, state 1); pupa with only two main trunks on the gill (character 31 , state 1 ); larval hypostoma with all paralateral teeth reduced (character 46 , state 1); larval postgenal cleft deep (character 48 , state 1 ).

The analysis of Py-Daniel's (1982) data set resulted in three trees (Fig. 2). All trees support the monophyly of Lutzsimulium + Kempfsimulium, with seven synapomorphies. Also, analysis of his data resulted in ten autapomorphies for Kempfsimulium, which Py-Daniel (1982) used to support his new genus. Consequently, even under the data set of Py-Daniel (1982), the creation of a new monotypic genus is not heavily justified. Given that Lutzsimulium (sensu lato) is well supported and easily recognizable, there is no reason to maintain a monotypic genus. I propose to include Kempfsimulium as a junior synonym of Lutzsimulium.

In a phylogenetic analysis of the Simuliinae genera from the Southern Hemisphere (GIL-Azevedo \& MaiA-Herzog 2007) and here, A. iberaensis was recovered as the sister group of Lutzsimulium, and did not cluster with Araucnephia. However, this sister-group relationship is not only weakly supported, but relies on synapomorphies that are not easily recognizable: gonostylus height less than twice the wegth, but distinctly greater (character 19, state 1); facial and dorsal-scutum tri- chomes apex coiled (respectively: character 27, state 0; character 29, state 0 ). For these reasons I have chosen not to transfer A. iberaensis to Lutzsimulium. The problem is that A. iberaensis, the African Paracnephia, Procnephia, Araucnephioides and Araucnephia montana conserve many primitive features of the Simuliini. The position of those groups is uncertain and further investigation is necessary to clarify them.

What makes Lutzsimulium more enigmatic is that, in spite of presenting basal features of Simuliini, it shares many character states with Simulium (GIL-Azevedo \& MaiA-Herzog 2007), a genus of Simuliini considered to be highly derived. These features are: median arms of furcasternum (adult) with projections (character 7, state 1); basal cell (vein m-cu) absent (character 10, state 1); larval antennomere 3 with as long as or longer than $1+2$ (character 43 , state 1 ); mandibular serrations with less than seven teeth (character 44, state 1); hypostomal teeth reduced - next to the hypostomal plate, which partially covers the teeth (character 45, state 1); paralateral teeth reduced (character 46 , state 1); postgenal cleft deep (character 48 , state 1 ). As the monophyly of the clade Simulium ${ }^{2}$ (sensu GIL-AzEvedo \& Maia-Herzog 2007) is very strong, it is here hypothesized that those characters have evolved independently in both genera. Nevertheless, the occurence of so many homoplasies (seven at least) between Lutzsimulium and Simulium needs further investigation.
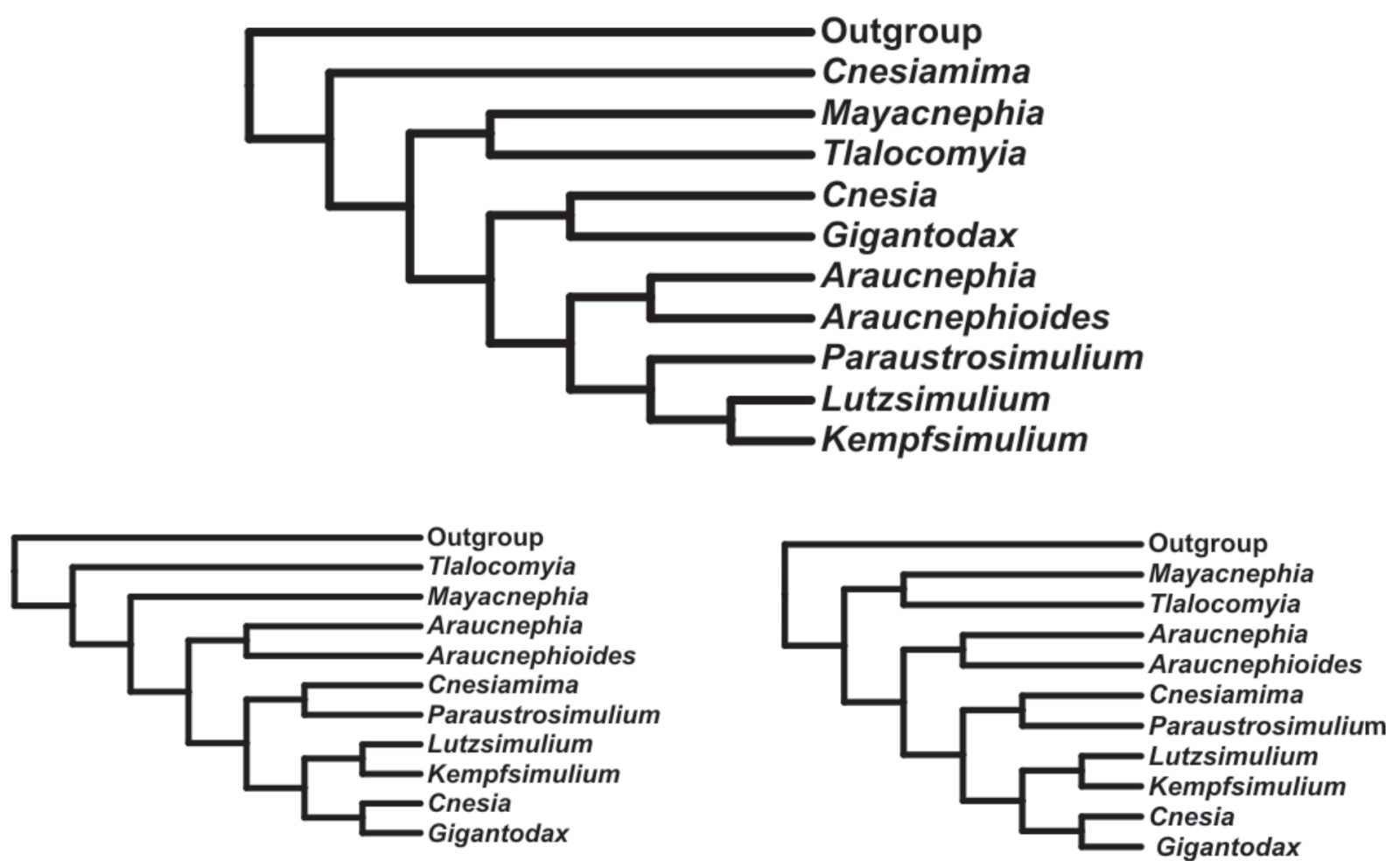

Figure 2. The three most parsimonious trees obtained from the analysis of Py-Daniel's (1982) data set.

ZOOLOGIA 27 (5): 761-788, October, 2010 
Based on phylogenetic and biogeographic data, two distinct groups can be recognized in Lutzsimulium. One group has three species (L. hirticosta, L. pernigrum, and L. flavopubescens), and is supported by five synapomorphies: paraproct (female terminalia) with a distinctly tail-like expansion (character 12, state 1 ); ventral plate (male terminalia) in dorsal view with medial portion narrower than the basal portion (character 21, state 0); and endoparamere reduced or absent (character 24, state 1); sexual dimorphism:pupal frontal trichomes absent in females and present in males (character 28, state 1); larval articles 1 and 2 unpigmented, contrasting with the dark antennomere 3 (character 41, state 1 ). Inside this group, $L$. pernigrum and $L$. flavopubescens are close species, a hypothesis corroborated by the following synapomorphies: larva with deep postgenal cleft subsquare (character 49 , state 2 ), and with irregular border (character 50, state 1 ). The other group is composed by a single highly autapomorphic species, L. simplicicolor, with five non-homoplasious autapomorphies: adult female with clypeus acute apex distinctly developed (character 3 , state 1 ); paraproct (female terminalia) with digit-like projection on the anterior and basal area (character 13, state 1); median sclerite of male terminalia without laterally pointed apex (character 23, state 0 ) and with distal area with teeth (character 22, state 1 ); and hypostoma of larva with $1+1$ paralateral teeth (character 47 , state 0 ). The fact that this species has many unique features probably led Py-DANIEL (1982) to place it in a monospecific genus, which was reassigned to subgenus status by (Crosskey \& Howard 1997). I think that a monotypic subgenus is redundant, especially for a genus with only four species.

\section{TAXONOMY}

\section{Lutzsimulium d'Andretta Jr \& Vulcano, 1947}

Figs 3-57

D'Andretta Jr \& Vulcano (1947): 401-402. D'Andretta Jr \& Vulcano (1948): 638-639. Vulcano \& D'Andretta Jr (1952): 307, 309-310, 312. Vulcano (1967): 16.4. Wygodzinsky \& Coscarón (1973): 140-144; 192-197. Py-Daniel (1982): 307308. Coscarón (1991): 78-79. Py-Daniel \& Sampaio (1994): 105, 111, 139. Py-Daniel \& Sampaio (1995): 119. Crosskey $\&$ Howard (1997): 16. Moulton (2000): 103. Moulton (2002): 53. Coscarón \& Coscarón-Arias (2002): 85, 87. Crosskey \& Howard (2004): 7. Coscarón \& Coscarón-Arias (2007): 102104. Gil-Azevedo \& Maia-Herzog (2007): 40-62. Adler \& Crosskey (2008): 23. Coscarón et al. (2008): 10. Adler \& Crosskey (2009): 24. Adler \& Crosskey (2010): 24. Shelley et al. (2010): 51-52, 147-152.

Type species. Lutzsimulium cruzi d'Andretta Jr \& Vulcano, 1947 (= L. hirticosta), by original designation.

Kempfsimulium Py-Daniel \& Nunes de Mello [in Py-Daniel, 1982] (synonymy). Py-Daniel (1982): 294-297, 300. Coscarón (1991): 78. Py-Daniel \& Sampaio (1994): 105, 111, 139. PyDaniel \& Sampaio (1995): 119. Coscarón \& Coscarón-Arias
(2007): 110-111. Gil-Azevedo \& Maia-Herzog (2007): 41-62. Lutzsimulium (Kempfsimulium) [as subgenus]: Crosskey \& Howard (1997): 16. Crosskey \& Howard (2004): 7. Adler \& Crosskey (2008): 23. Coscarón et al. (2008): 10. Adler \& Crosskey (2009): 24.

Type species. Simulium simplicicolor Lutz, 1910, by original designation.

Diagnosis. Adult: mandible (female) with teeth developed just on the internal side; median arms of furcasternum with projections (Fig. 5); hind leg with the subbasal tooth of the claw reduced, smaller than a third of the main tooth (Fig. 8); wing basal cell (vein m-cu) absent (Fig. 6). Female terminalia: spermatheca and half of spermathecal duct pigmented; spermatheca neck surface and spermathecal duct with net-like structure (Figs 12 and 47). Male terminalia: gonostylus length less than 2/3 of the gonocoxite; gonostylus height less than twice the base, but distinctly greater (Figs 13 and 48). Pupa: apex of facial and dorsal-scutum trichomes coiled; gill with two main trunks (Fig. 17). Larva: mandibular serrations with less than 6 teeth; antennomere 3 equal to or longer than $1+2$ (Fig. 21); hypostomal teeth reduced - next to the hypostomal plate, which covers partially the teeth (Figs 22 and 56); hypostoma with $1+1$ or $2+2$ reduced paralateral teeth (Figs 22 and 56); postgenal cleft deep, extended anteriorly about one third or more the distance to hypostomal groove (Figs 23 and 32).

Systematic notes. Py-Daniel \& Nunes de Mello in Py-DANIEI (1982) created Kempfsimulium to place L. simplicicolor, but CrosskeY $\&$ Howard $(1997,2004)$ synonymized this genus with Lutzsimulium without any justification. Moulton $(2000,2002)$ tentatively transferred Lutzsimulium to Simuliini, which was confirmed later (GIL-AzEvedo \& MAIA-Herzog 2007). Based on the cladistic approaches on the Simuliidae of Southern Hemisphere of Gil-Azevedo \& Maia-Herzog (2007) and here justify the synonymy of Kempfsimulium with Lutzsimulium. Recently, SHeLLey et al. (2010) proposed the synonymy of Araucnephia Wygodzinsky \& Coscarón, 1973 and Araucnephioides Wygodzinsky \& Coscarón, 1973 with Lutzsimulium, based on "morphological similarities", but they did not explain what similarities. Also, they ignored the fact that Lutzsimulium, Araucnephia and Araucnephioides do not seem to form a monophyletic group (GIL-Azevedo \& MaiAHerzog 2007, and here). Their synonymy creates an unnatural taxon that is inappropriate according the modern taxonomy. Therefore, I propose that the status of Araucnephia and Araucnephioides should be revalidated.

Distribution and biology. The genus occurs in the eastern side of South America and seems to be strongly correlated with forest and other humid areas. The distribution area is disjoint, ranging from northeastern and southeastern Brazil to northeastern Argentina, and also in the south and east borders of Amazonia (Brazil) (Figs 58-60). This disjoint distribution may be caused by the presence of the South American semi-arid diagonal, which ranges from northeastern Brazil to the northwestern Argentina. 
Simuliidae are viewed as a pest most of the time but, like other insects, they also suffer a risk of extinction, mainly caused by the destruction of their habitat. Three species of Lutzsimulium need some attention because of their restricted habitats. $L$. flavopubescens was only found in a restricted area in Itatiaia mountain range, and probably is endemic of that region. Luckily, that area is inside one of the most important Brazilian National Parks, the first to be created in Brazil. Lutzsimulium pernigrum is restricted to altitudinal relict areas, which need to be preserved, and L. hirticosta is also related to areas of low anthropic impact. The biology and ecology of those species need more studies because maybe they could serve as useful bioindicators of the state of preservation of areas.

\section{Keys to the species of Lutzsimulium}

\section{Adult}

1. General coloration of thorax yellow. Female - clypeus acute apex distinctly developed (Fig. 42); spermatheca with netlike structure present only in the duct (Fig. 47); paraproct without a distinctly tail-like expansion and with a digit-like projection in the anterior and basal area (Fig. 45). Male ventral plate in dorsal view with medial portion wider than basal (Fig. 49); endoparamere developed ..... L. simplicicolor

1 '. General coloration of thorax black or light brown. Female clypeus acute apex normal (Fig. 3); spermatheca with netlike structure present in spermatheca neck and duct (Fig. 12); paraproct with a distinctly tail-like expansion and without a digit-like projection in the anterior and basal area (Figs 10, 27 and 36). Male - ventral plate in dorsal view with medial portion narrower than basal (Figs 14 and 15); endoparamere reduced or absent . ... 2

2. General coloration of thorax light brown; length of the last palpomere distinctly longer than the penultimate (male and female) L. hirticosta

2 '. General coloration of thorax black; length of the last and of the penultimate palpomeres approximately equal (male and female) 3

3. Female - paraproct length distinctly longer than cerci (Fig. 36); clypeus longer than wide ....................... L. pernigrum

3 '. Female - paraproct length equal to the cerci (Fig. 10); clypeus as long as wide ...................................... L. flavopubescens

The Males of L. pernigrum and L. flavopubescens are indistinguishable.

\section{Pupa}

1. 12 terminals gill filaments .. 2

$1^{\prime}$. More than 12 terminals gill filaments ............................... 3

2. Terminals gill filaments long, slender, and not grouped (Fig. 17); presence of cephalothoracic tubercles; in females, frontal trichomes absent; IV segment of abdomen without ventral hooks (Fig. 18) L. flavopubescens

2 '. Terminal gill filaments short, thickened, and grouped (Fig.
51); absence of cephalothoracic tubercles; in females, frontal trichomes present; IV segment of abdomen with $2+2$ ventral hooks (Fig. 52) . L. simplicicolor

3. 14 terminals gill filaments; cephalothorax without tubercles L. pernigrum

3 '. From 20 to 22 terminals gill filaments; cephalothorax with many tubercles .... L. hirticosta

\section{Larva}

1. All the articles of the antenna equally unpigmented; $1+1$ reduced paralateral teeth (Fig. 56) .............. L. simplicicolor

1'. Articles 1 and 2 unpigmented, contrasting with dark antennomere $3 ; 2+2$ paralateral teeth (Fig. 22) ............... 2

2. Larval body tegument with hairs; antennomere 1 longer than 2 (Fig. 31); postgenal cleft with rounded shape and regular border (Fig. 32) . .L. hirticosta

2 '. Larval body tegument glabrous; antennomere 1 shorter than or equal to 2 (Figs 21 and 40); postgenal cleft with subsquare shape and irregular border (Figs 22 and 41 ) ................... 3

3. Dissected histoblastic gill with 14 filaments; antennomere 2 lesser than twice longer than antennomere 1 (Fig. 40) ....

L. pernigrum

3'. Dissected histoblastic gill with 12 filaments, antennomere 2 twice as long as antennomere 1 (Fig. 21)

L. flavopubescens

\section{Lutzsimulium flavopubescens (Lutz, 1910) Figs 3-24}

Simulium flavopubescens: Lutz (1910): 248-249, 261, 263, 265266, figs 17, 18. Pinto (1930): 477, 481. Pinto (1932): 702, 726, 756. Smart (1945): 505. Vargas (1945): 138. Vulcano (1967): 16.12. Vulcano (1977): 291. Vulcano (1981): 276. Eusimulium flavopubescens: Surcouf \& Gonzalez-Rincones (1911): 280. Lane \& Porto (1939): 169, 175 [probably not $L$. flavopubescens Lutz]. Lane \& Vulcano (1943): 434, 436, figs 8, 28 [probably not $L$. flavopubescens Lutz]. Forattini et al. (1971): 357 [probably not L. flavopubescens Lutz]. Lutzsimulium flavopubescens: Py-Daniel (1982): 308-311, fig. 15 A-K, 16 HN, 17 O-S, 18 A-G,19 A-H, [20 A-D probably not $L$. flavopubescens Lutz]. Coscarón (1991): 82. Py-Daniel \& Sampaio (1994): 111. Py-Daniel \& Sampaio (1995): 119. Amaral-Calvão \& Maia-Herzog (2003): 267-268. Gil-Azevedo et al. (2005b): 743, 746. Coscarón \& Coscarón-Arias (2007): 104-105, 109. Gil-Azevedo \& Maia-Herzog (2007): 41, 43-45, $47-48,50,57,66$, fig. 1B, 3D, 4A, 7H. Coscarón et al. (2008): 11. Shelley et al. (2010):19, 52, 77, 152-154, 596. Gil-Azevedo \& Maia-Herzog (2010): 350. Lutzsimulium (Lutzsimulium) flavopubescens: Crosskey \& Howard (1997): 16. Crosskey \& Howard (2004): 7. Adler \& Crosskey (2008): 23. Adler \& Crosskey (2009): 24. Adler \& Crosskey (2010): 24.

Types. LECTOTYPE = LUTZ-IOC 12,112 (1 pupa/female slide). PARALECTOTYPE = LUTZ-IOC 12,113 (2 pupae slide); 12,114 

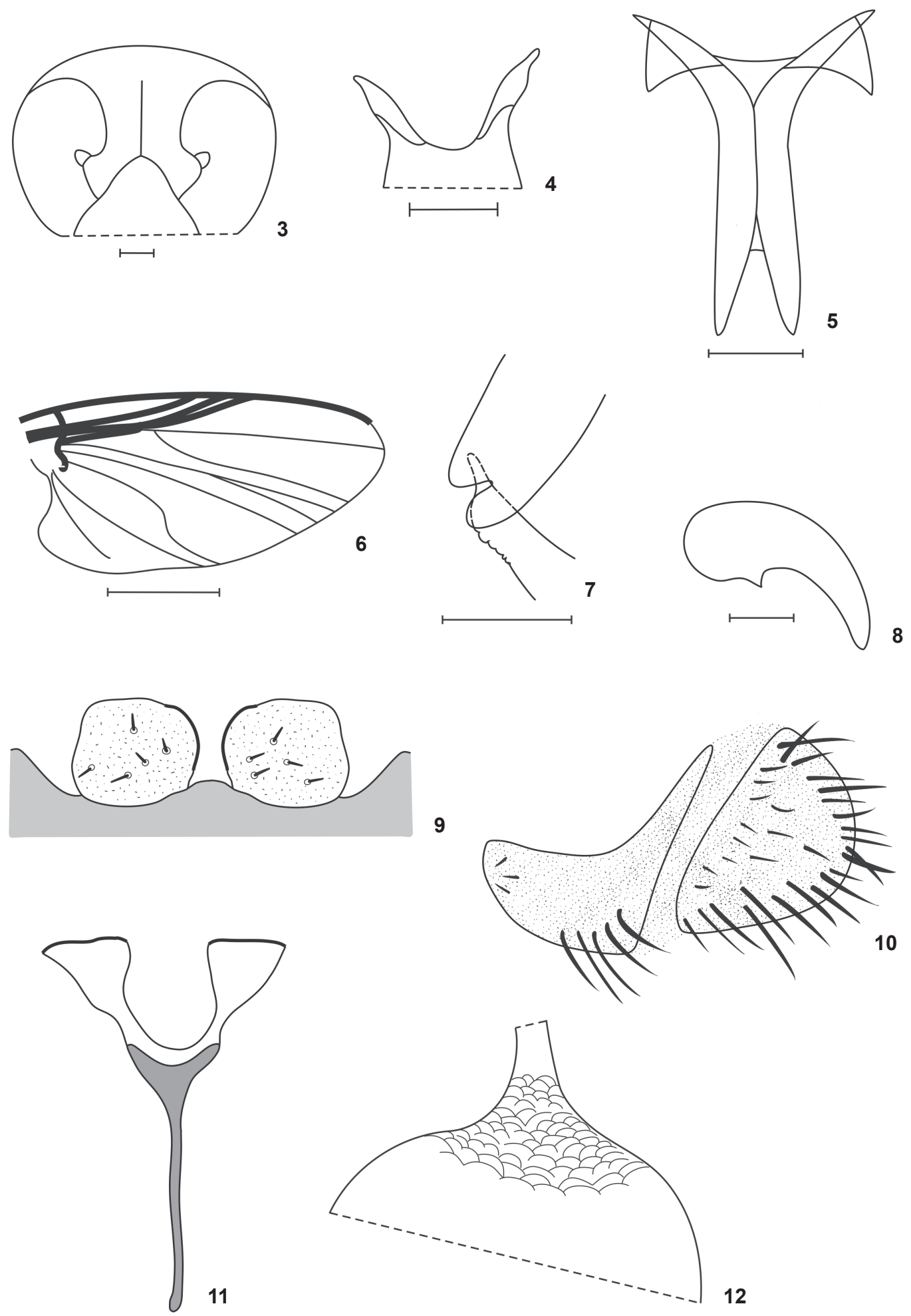

Figures 3-12. Female of L. flavopubescens: (3) head; (4) cibarium; (5) furcasternum; (6) wing; (7) calcipala and pedisulcus; (8) claw; (9) hypogynial valve; (10) cerci and paraproct; (11) genital fork; (12) spermatheca. Bar: $3-5$ and $7=0.1 \mathrm{~mm}, 8=0.01 \mathrm{~mm}$. 

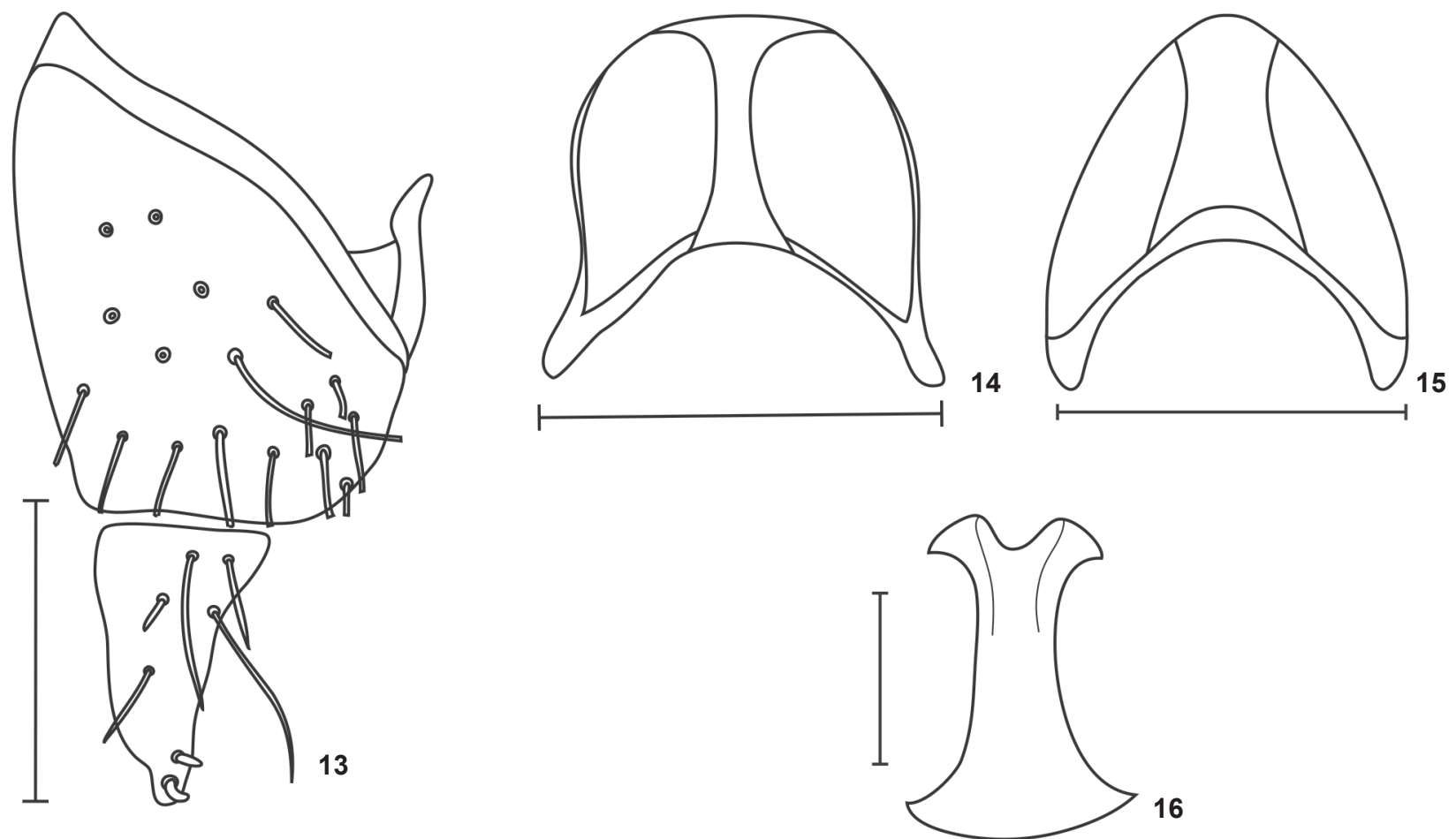

Figures 13-16. Male of L. flavopubescens: (13) gonocoxite and gonostylus; (14-15) ventral plate in two different dorsal views; (16) median sclerite. Bar: $0.1 \mathrm{~mm}$.

(1 pupa slide); 12,115 (1 pupa slide); 12,116 (1 pupa slide); 12,117 (1 larval gill histoblast slide); 12,119 (1 larva slide); 12,121 (1 pupa slide), BrazIL, Rio de Janeiro: Itatiaia.

Specimens before considered as belonging to the type series: LUTZ-IOC 12,118 (1f slide) - it is Simulium sp.; 12,120 (1 larva slide, poorly preserved) - it is L. hirticosta according to PyDaniel (1982); 12,521 A, B, (2f pinned, poorly preserved) - B dissected, it is L. pernigrum.

Description. Female. General body color black. Body length 2.4-2.7 mm $(\mathrm{n}=2)$; mesothorax length 1.1-1.4 mm, mesothorax width $0.8-0.9 \mathrm{~mm}(\mathrm{n}=4)$; wing length $2.4 \mathrm{~mm}$, wing width $0.9 \mathrm{~mm}(\mathrm{n}=1)$. Head dichoptic with black eyes, with reddish edge; nudiocular area small and rounded (Fig. 3). Frons, clypeus and occiput black with silver pruinosity and many long copper bristles; frons higher than wide and with a medial suture (Fig. 3), clypeus as wide as long and with acute apex (Fig. 3). Antennae with silver pruinosity; scape and pedicel light brown, flagellomeres black. Mouthparts dark; palp and labium black with silver pruinosity, labrum reddish. Mandible with about 35 teeth on internal side, without teeth on external side. Maxilla with about 14 teeth each side; palp with the last and the penultimate palpomeres approximately equal; Lutz's organ length about $1 / 3$ of basal article length. Cibarium unarmed, with reduced and sclerotized cornua (Fig. 4). Scutum and postpronotal lobe entirely dark brown, with silver pruinosity and many copper bristles uniformly distributed. Scutellum dark brown with silver pruinosity and many long black bristles. Postnotum and pleural region black with silver pruinosity. Medium arms of furcasternum with projections (Fig. 5). Chaetotaxy of wing veins, $C$ and $R_{1}$ with hair-like and spinelike setae; Sc with an only row of hair-like setae; basal portion of $\mathrm{R}$ and Rs with hair-like setae; vein Rs unbranched and basal cell absent (Fig. 6). Halteres entirely black. The coloration pattern of the legs is not obvious. Hind leg with calcipala present (basitarsus) and a shallow pedisulcus (Fig. 7). All legs with many long copper bristles. All leg claws bearing small triangular subbasal tooth (Fig. 8). Abdomen entirely black with many long copper bristles. Hypogynial valve distally straight; inner margins slender, sclerotized and subparallel, diverging distally (Fig. 9). Cerci hemispheric, with width more than twice of the height; paraproct square and small, with anterior area high and posterior area narrow resembling a tail and with setae only in anterior side; length of paraproct and of cerci similar sized (Fig. 10). Genital fork stem as long as lateral plates; lateral plates short and broad, with a triangle form, and posterior edge straight and sclerotized; stem entirely pigmented and lateral plates unpigmented; lateral plates forming a oval space (Fig. 11). Spermatheca spherical and entirely pigmented; surface of the spermathecal duct and insertion area of the spermatheca with net-like structure (Fig. 12). 

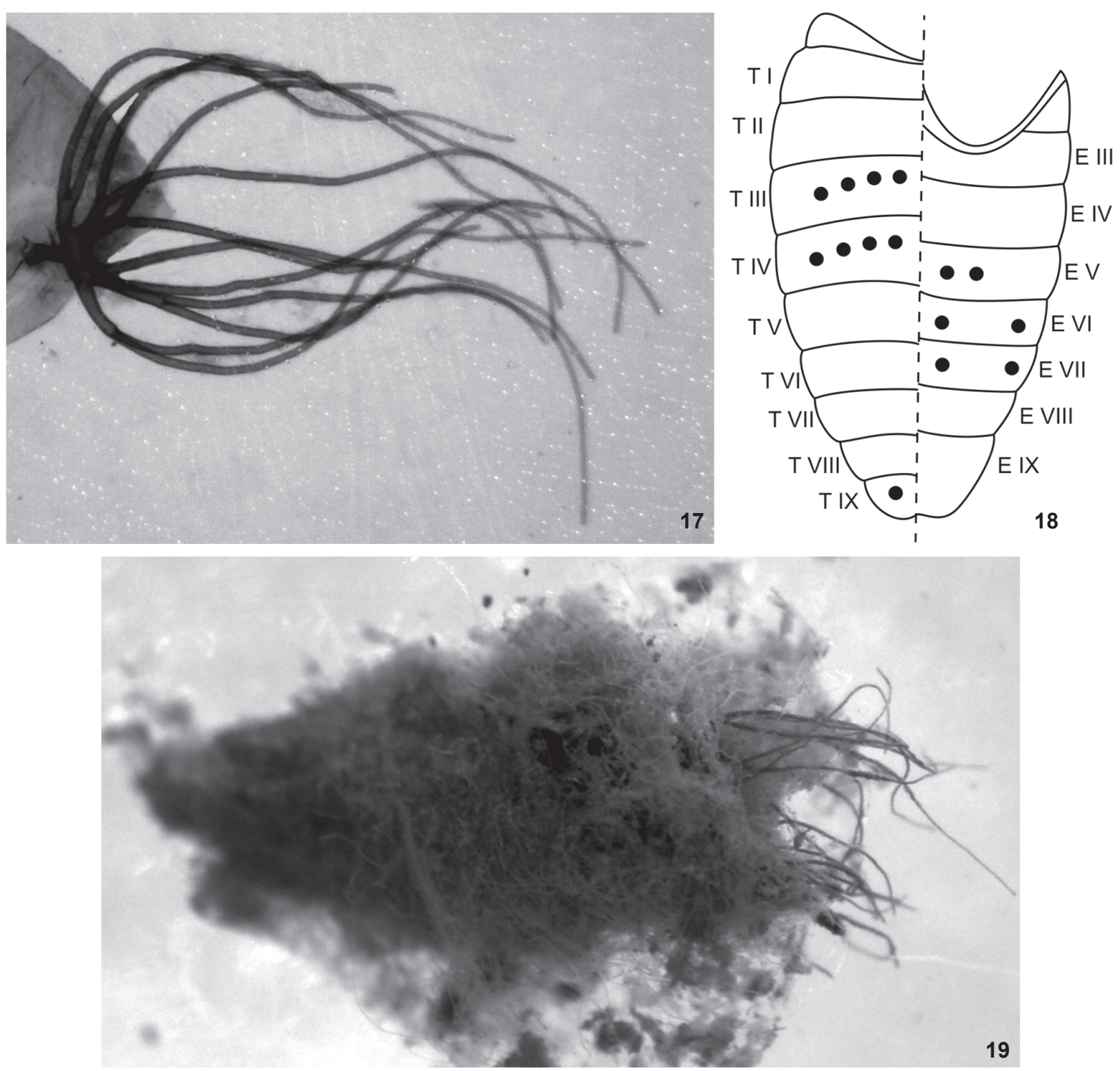

Figure 17-19. Pupa of L. flavopubescens: (17) gill; (18) abdominal chaetotaxy (round black dots represent hooks distribution); (19) pupa and cocoon.

Male. General body color black. Body length 2.9-3.2 mm $(\mathrm{n}=2)$; mesothorax length 1.1-1.2 mm, mesothorax width 0.9 $\mathrm{mm}(\mathrm{n}=2)$; wing length $1.9-2.7 \mathrm{~mm}$, wing width 0.8-1.2 $\mathrm{mm}$ $(\mathrm{n}=3)$. Head holoptic with black reddish eyes. Frons, clypeus, mouthparts, occiput and antennae colorations as in female, except for the dark red scape of the antenna. Lutz's organ length about $1 / 6$ of basal article length. Thorax coloration entirely black, with silver pruinosity and many copper bristles uniformly distributed; furcasternum, wing veins, halteres coloration, and legs as in female. Abdomen as in female. Gonocoxite small, length almost the same of the gonostylus; gonocoxite with trapezium shape, so that the right side is smaller than the left and the greater width and the greater height sub-equal (Fig. 13). Gonostylus canine-like, with height less than twice the base, but distinctly greater than base; apex with two developed spinules (apical + sub-apical) (Fig. 13). Ventral plate hemispheric with sclerotized basal arms, medium area high, lateral margins convex and concave pointed apex (Figs 14 and 14). Ventral plate and gonostylus similar in size. Median sclerite elongated, flattened and hourglass shape; with enlarged base, middle with 

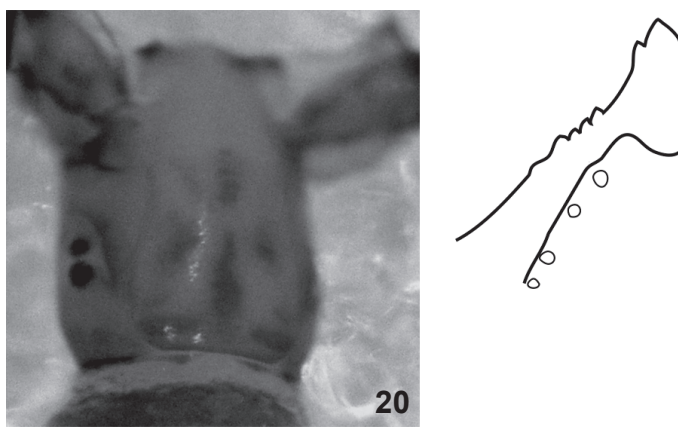

20

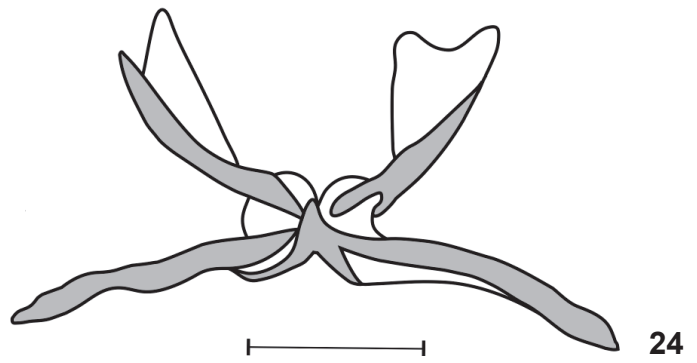

24

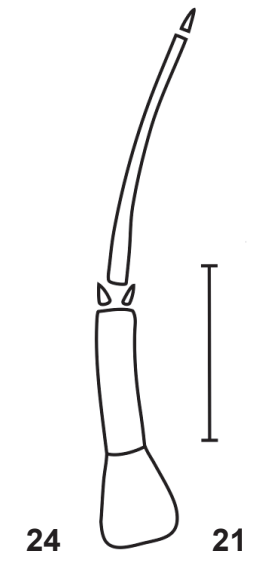

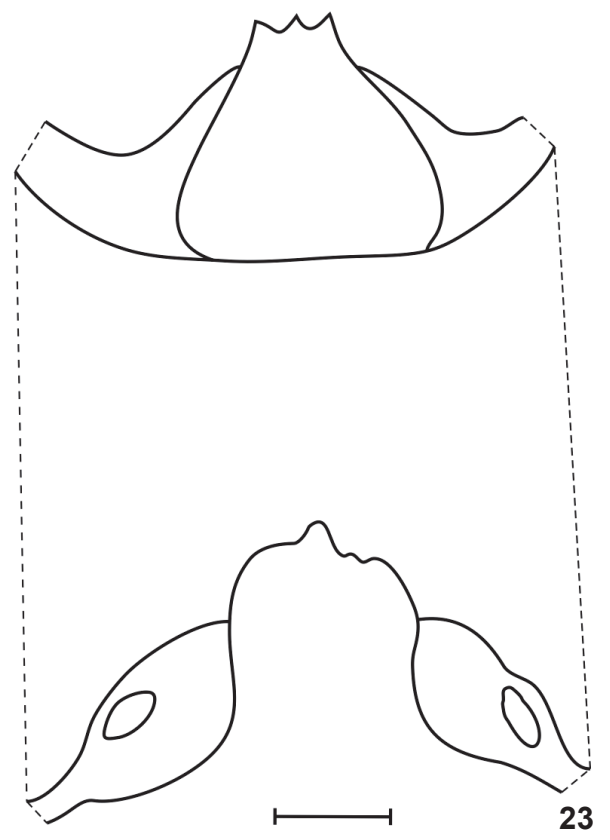

Figure 20-24. Larva of L. flavopubescens: (20) head capsule, dorsal view; (21) antenna; (22) hypostomal teeth; (23) head capsule, ventral view; (24) anal sclerite. Bar: $0.1 \mathrm{~mm}$.

a constriction, and lateral pointed and sclerotized apex, with a membrane between the points (Fig. 16). Paramere and dorsal plate absent.

Pupa. Length 3.2-4.6 mm ( $\mathrm{n}=10)$; gill length 1.0-1.7 $\mathrm{mm}(\mathrm{n}=10)$. Gill with 12 gill filaments branching in a dichotomous way (arborescent) and directed forward (Fig. 17); the basal stalk immediately giving rise to two main trunk each with six filaments $[2+(2+2)]+[2+(2+2)]$ (Fig. 17); all filaments with equal length and width; surface of gill filaments smooth; apex of all filaments digit-like. Head and thorax surface light cracked with few small rounded tubercles with a random distribution; head with $2+2$ frontal trichomes only in male (none in female), 1+1 facial trichomes; thorax with $6+6$ dorsalscutum trichomes; all the trichomes simple and hair-like; trichomes of the dorsal-scutum region and facial trichomes with coiled apex. Abdomen well sclerotized, majority of plates sclerotized and with small rounded tubercles and setae; pleurites of the abdomen reduced to striated areas with a small plate that carries the hook. Abdominal chaetotaxy (Fig. 18), tergites III-IV each with $4+4$ anteriorly directed hooks long and thin (similar to the ventral hooks); tergites VI-IX each with a transverse row of small comb spines on anterior margin; tergite IX with 1+1 developed and slightly curved terminal spines; segment IX with many simple, long and curve (cane-like) terminal setae. Sternite IV without hooks; sternite V with $2+2$ anteriorly directed simple hooks; sternites VI-VII with $1+1$ anteriorly directed simple hooks. Pleurites VI-VII with $1+1$ anteriorly directed simple hooks. Cocoon (Fig. 19) light brown, with shape not defined, ill-formed and asymmetrical; anterior and ventral rim not defined; cocoon often covering all the body and gill, and often with debris.

Larva (final instar). General coloration light brown. Maximum length 6.7-7.5 mm $(\mathrm{n}=10)$; head capsule dorsal length 1.0-1.1 $\mathrm{mm}$ and dorsal width 0.7-0.8 $\mathrm{mm}(\mathrm{n}=10)$; gill histoblast length, in situ $0.4 \mathrm{~mm}$ and width $0.2 \mathrm{~mm}(\mathrm{n}=10)$. Head capsule (in dorsal view) with dark spots, $1+1$ posterolateral spots, a posteromedial and a discontinuous anteromedial spot (with 4 subspots), and $2+2$ anterolateral spots (Fig. 20). Head capsule without setae. Cervical sclerites small and rounded, isolated from the postocciput (Fig. 20). Antennae with proximal and medial articles unpigmented, contrasting with dark distal article; proximal article broad and short; medial article twice as long as proximal; distal article thin and longer than proximal + medial (Fig. 21). Stalk of labral fan distinctly longer than antennae; labral fan with 49-51 rays. Mandibular teeth, 1 apical, 2 external, 1 subapical, about 10 internal teeth and 5 mandibular serration. Hypostomal teeth reduced and next to the hypostomal plate, which covers partially the teeth; hypostoma with median tooth equal height to the $1+1$ lateral teeth; with $3+3$ sublateral teeth and $2+2$ paralateral teeth; lateral margin of hypostoma with about four serrations per side; hypostoma with $4+4$ setae (Fig. 22). Postgenal cleft deep, higher than wide and with subsquare shape and with irregular border (Fig. 23); postgenal bridge longer than hypostoma (Fig. 23). Subesophageal ganglion slightly pigmented. Thorax and abdomen without setae. Abdomen clublike, with rounded distal apex. Thorax ventral and lateral re- 
gions white, contrasting with dorsal region of thorax and abdomen light brown. Abdomen without ventral tubercles; anal sclerite X-shaped, ventral arm distinctly longer than the dorsal one (Fig. 24); rectal organ with three simple lobes; anal ring with about 110 rows of $15-20$ hooks each.

Examined material. LUTZ-IOC: BRAZIL, Rio de Janeiro: Itatiaia, 1 pupa/female, 6 pupae, 2 larvae (slide) (\#12,112; 12,113; $12,114 ; 12,115 ; 12,116 ; 12,117 ; 12,119 ; 12,121)$. LSO-IOC BRAZIL, RJ, Itatiaia (Agulhas Negras, $\left.22^{\circ} 22^{\prime} 38^{\prime \prime} \mathrm{S} 44^{\circ} 41^{\prime} 36^{\prime \prime} \mathrm{W}\right), 4 \mathrm{fe}-$ males and 2 males with pupal pelts (pinned), 20 pupae, 20 larvae (spirit), 3 females and 2 males with pupal pelts, 7 larvae (slides), 07/VI/2004, L.Gil-Azevedo \& R.Figueiró leg.

Distribution. BrazIL, Rio de Janeiro: Itatiaia (Agulhas

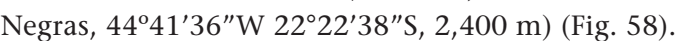

Remarks. This species was described by LuTz (1910) based in some specimens collected in Itatiaia, next to the Agulhas Negras mountain range (about 2,400 m). All the discussion in the literature on this species is based on the type material, which consists of few pupae mounted in slides and three poorly preserved females. The male was hitherto unknown and the larva described by Lutz in the original description has been later shown to belong to L. hirticosta (Py-Daniel 1982). Lane \& Porto (1939) identified a female collected in Campos do Jordão (FSPUSP 1,222$)$ as L. flavopubescens. This female, mounted in slide by Py-Daniel, has been damaged by postal handling and according to him this specimen could be referred to any Lutzsimulium species, but, probably not to L. flavopubescens due to small differences (Py-DANiel 1982). So, Campos do Jordão is a dubious record, and until now $L$. flavopubescens is endemic to Itatiaia. This species was the last to be transferred to Lutzsimulium (Py-Daniel 1982), probably because of the little available information. Almost one century after the original description, this species was rediscovered in Itatiaia, and abundant material was collected, so it is possible to provide here descriptions of male and larva, and more complete redescriptions of female and pupa.

Biological and distributional notes. Larvae and pupae were found in small, temporary stream which was located in an open area in highlands $(2,400 \mathrm{~m})$. The immatures were found grouped, with the cocoons connected, on the mud in water at $4^{\circ} \mathrm{C}$.

\section{Lutzsimulium hirticosta (Lutz, 1909)}

Figs 25-33

Simulium hirticosta: Lutz (1909): 132, 135. Lutz (1910): 226-228, 261, 264-266, fig. 16. Surcouf \& Gonzalez-Rincones (1911): 287-288. Pinto (1930): 481-482. Pinto (1932): 702, 726, 756. Smart (1945): 506. Vargas (1945): 144. Vulcano (1962): 239. Simulium (Eusimulium) hirticosta: Floch \& Abonnenc (1946): 8. Lutzsimulium hirticosta: Vulcano (1967): 16. 4.Wygodzinsky \& Coscarón (1973): 195-197, fig. 42 A-S. Vulcano (1977): 291. Vulcano (1981): 276. Coscarón (1981): 45. Py-Daniel (1981): 174. Py-Daniel (1982): 305, 311-312, fig. 13 B, 14 C-D. Coscarón (1991): 80-81, fig. 16 A-J, 17 A-N. Coscarón et al.
(1992): 111, 113, 118. Dellome Filho (1991): 147, 152-153, figs 22, 23. Py-Daniel \& Sampaio (1994): 112. Py-Daniel \& Sampaio (1995): 119. Strieder (2002): 131, 133-136. Strieder et al. (2002): 534-537. Amaral-Calvão \& Maia-Herzog (2003): 261-262, 267-268. Pepinelli et al. (2003): 654. Lozovei et al. (2004): 94. Strieder (2004): 116. Gil-Azevedo et al. (2005b): 743, 746, fig. 3. Strieder et al. (2006): 121-123. Coscarón \& Coscarón-Arias (2007): 104-108, figs 24 A-J, 25 A-N. Gil-Azevedo \& Maia-Herzog (2007): 41, 43, 55-56, 58, 66, fig. 6B. Coscarón et al. (2008): 11. Landeiro et al. (2009): 335-336. Shelley et al. (2010):19, 52, 77, 154-157, 596, figs 65, 73, 81, 165, 250-251, 424, 502, 585, 669, 752-753, 906, 987, 1065, 1140. Gil-Azevedo \& Maia-Herzog (2010): 350. Lutzsimulium (Lutzsimulium) hirticosta: Crosskey \& Howard (1997): 16. Crosskey \& Howard (2004): 7. Adler \& Crosskey (2008): 23. Adler \& Crosskey (2009): 24. Adler \& Crosskey (2010): 24.

Types. 2 females, Brazil, SP, São Paulo [lost].

Simulium hirticola (typographic error): Pinto (1930):477. Eusimulium hirticola: Lane \& Porto (1939):169.

Lutzsimulium cruzi: d'Andretta Jr \& Vulcano (1947): 401-412, figs 1-35. d'Andretta Jr \& Vulcano (1948): 639-647, figs 138. Vulcano (1962): 239, 244. Stone (1963). Forattini et al. (1971): 359.

Types. HOLOTYPE: 1 female (1,161 FSP-USP), BrazIL, SP, Bragança Paulista. PARATYPES: females and pupae $(1,332$ and 1,333 FSP-USP), BraZIL, SP, Bragança Paulista. The Allotype (1 male 1,261 MZSP) is invalid.

Description. Female. General body color brown. Body length 1.7-2.1 mm $(\mathrm{n}=2)$; mesothorax length 0.9-1.1 mm, mesothorax width 0.7-0.9 mm $(\mathrm{n}=4)$; wing length $2.3 \mathrm{~mm}$, wing width 1.0-1.2 mm $(\mathrm{n}=3)$. Head, eyes, nudiocular area, frons, clypeus, occiput, and antennae as L. flavopubescens (Fig. 3). Mouthparts dark; labrum, labium and palp brown with copper bristles. Mandible with about 25 teeth on internal side, without teeth on external side. Maxilla with about 12 teeth each side; palp with the last palpomere larger than penultimate; Lutz's organ length about $1 / 2$ of basal article length. Cibarium as $L$. flavopubescens (Fig. 4). Scutum entirely light brown and postpronotal lobe dark brown, with silver pruinosity and many copper bristles uniformly distributed. Scutellum light brown with silver pruinosity and many long black bristles. Postnotum and pleural region brown with silver pruinosity. Medium arms of furcasternum with projections (Fig. 5). Chaetotaxy of wing veins as $L$. flavopubescens. Halteres entirely dark brown. Legs as $L$. flavopubescens (Fig. 8), calcipala and pedisulcus (Fig. 25). Abdomen as L. flavopubescens. Hypogynial valve (Fig. 9), genital fork (Fig. 26), and spermatheca (Fig. 12) as L. flavopubescens. Cerci and paraproct shape as $L$. flavopubescens; paraproct longer than cerci (Fig. 27).

Male. General body color brown. Body length 1.8-2.1 mm $(\mathrm{n}=3)$; mesothorax length $0.8-1.0 \mathrm{~mm}$, mesothorax width 0.7 $\mathrm{mm}(\mathrm{n}=5)$; wing length 1.9-2.4 mm, wing width $0.8-1.0 \mathrm{~mm}$ $(\mathrm{n}=3)$. Head holoptic with black reddish eyes. Frons, clypeus, 

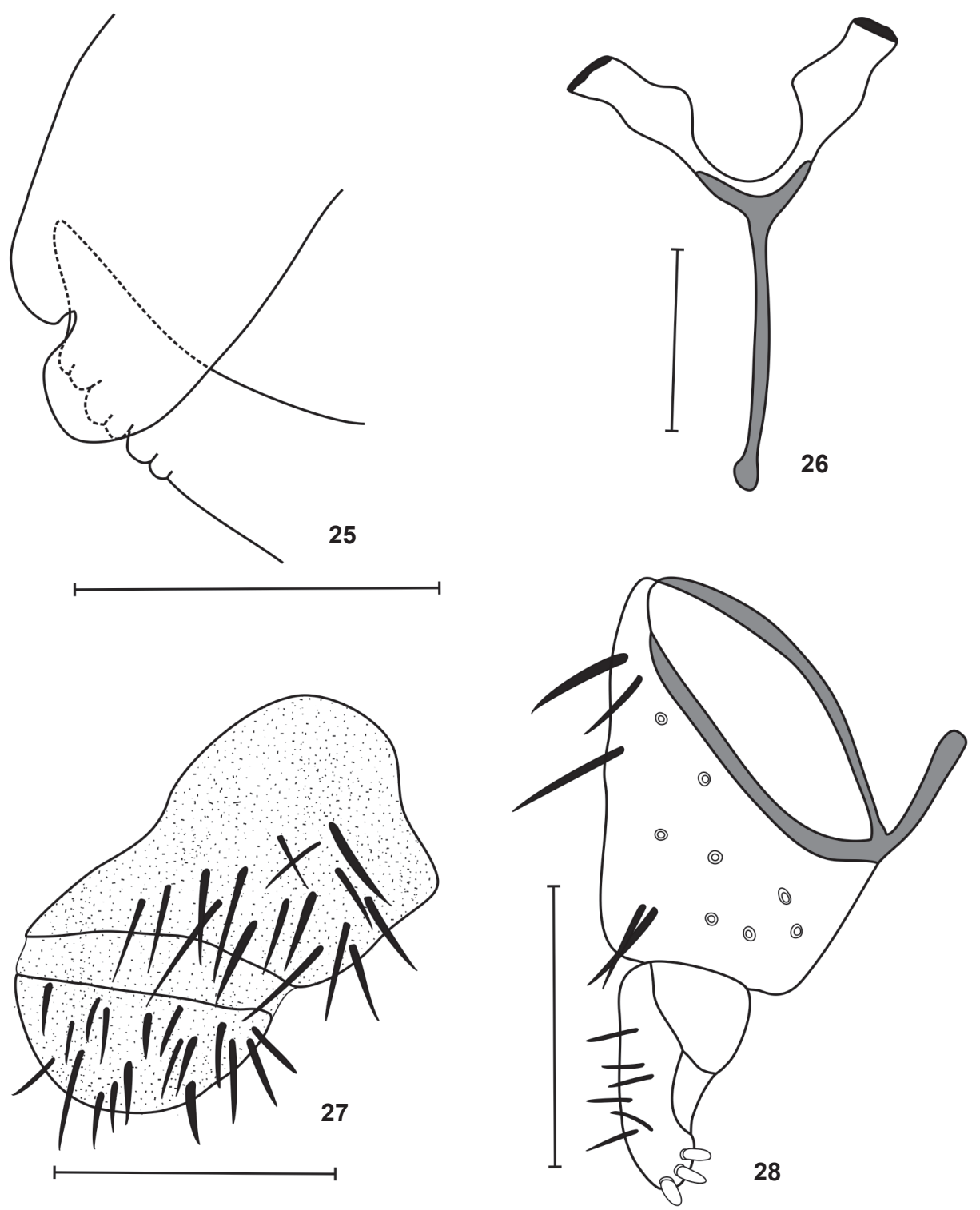

Figure 25-28. Adult of L. hirticosta: (25-27 female) (25) calcipala and pedisulcus; (26) genital fork; (27) cerci and paraproct. (28) male, gonocoxite and gonostylus. Bar: $0.1 \mathrm{~mm}$.

mouthparts, occiput and antennae colorations as in female. Lutz's organ length about $1 / 4$ of basal article length. Thorax coloration, furcasternum, wing veins, halteres coloration, and legs as in female. Abdomen as in female. Gonocoxite shape as L. flavopubescens, but the length is a little longer than the gonostylus (Fig. 28). Gonostylus as L. flavopubescens; gonostylus apex with three or four developed spinules ( 1 apical +2 or 3 sub-apical) (Fig. 28). Ventral plate and gonostylus similar sized. Ventral plate (Figs 14 and 15) and median sclerite (Fig. 16) as $L$. flavopubescens. Paramere and dorsal plate absent.
Pupa. Length 3.1-3.4 mm $(\mathrm{n}=10)$; gill length 1.9-2.5 $\mathrm{mm}(\mathrm{n}=10)$. Gill with $19-24$ gill filaments branching in a dichotomous way (arborescent) and directed forward (Fig. 29); the basal stalk immediately giving rise to two main trunk each with nine to eleven filaments $[(2+2)+((2+2)+2)]+[(1+2)$ $+((2+2)+2)]$; filaments as $L$. flavopubescens. Head and thorax surface light cracked with many small rounded tubercles with aleatory distribution; head and thorax chaetotaxy as $L$. flavopubescens. Abdomen, abdominal chaetotaxy (Fig. 18), and cocoon (Fig. 30) as L. flavopubescens. 

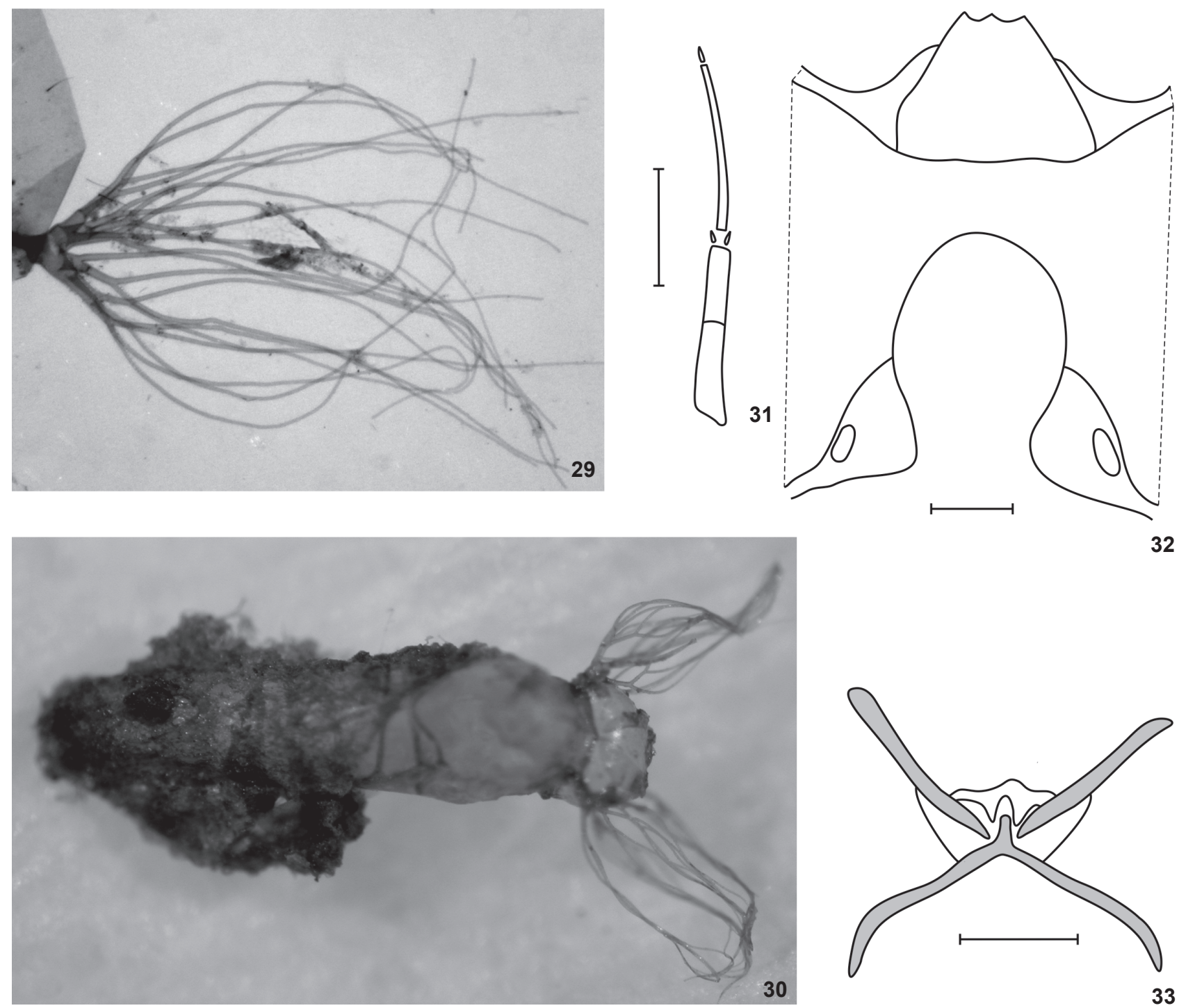

Figure 29-33. Immatures of L. hirticosta: (29-30 pupa) (29) gill; (30) pupa and cocoon. (31-33 larva) (31) antenna; (32) head capsule, ventral view; (33) anal sclerite. Bar: $0.1 \mathrm{~mm}$.

Larva (final instar). General coloration light brown. Head capsule pattern (in dorsal view) and cervical sclerites as $L$. flavopubescens (Fig. 20). Head capsule covered by small setae. Antennae as L. flavopubescens, except proximal article longer than medial (Fig. 31). Stalk of labral fan distinctly longer than antennae; labral fan with 30-32 rays. Mandibular teeth, 1 apical, 2 external, 1 subapical, about 12 internal teeth and 2 mandibular serration. Hypostoma and hypostomal teeth as $L$. flavopubescens (Fig. 22). Postgenal cleft deep, higher than wide, with oval shape and regular border (Fig. 32); hypostoma longer than postgenal bridge (Fig. 32). Subesophageal ganglion slightly pigmented. Thorax and abdomen shape and coloration as $L$. flavopubescens. Thorax and abdomen covered by small setae. Anal sclerite X-shaped, ventral and dorsal arms similar sized (Fig. 33); rectal organ with three simple lobes; anal ring with about 64 rows of 12-13 hooks each.

Examined material. MLP: Argentina, Misiones, $15 \mathrm{~km}$ S.E. Deseado, 1 female with pupal pelt (slide), 20/VIII/1972, S. Coscarón leg. BraziL, RJ, Angra dos Reis (km 58), 1 female with pupal pelt (slide), 29/VIII/1979, S. Coscarón leg. 1 male with pupal pelt (slide) (MLP). 1 larva (slide). LUTZ-LSO: BraZIL, RJ, Petrópolis, 6 females and 4 males (pinned) \#12,525, 12,528, 12,529, 12,530, $12,531,12,532.1$ pupa (slide) \#12,416. 1 pupa (slide) \#12,417. 1 pupa (slide) \#12,418. 1 pupa (slide) \#12,419. 1 pupa (slide) 
$\# 12,422.1$ pupa (slide) \#12,424. 1 male (slide) \#12,423. (LUTZLSO). LSO-IOC: BraziL, RJ, Duque de Caxias (Floresta de Xerém), 4 females and 4 males with pupal pelts (pinned), 1 female and 1 male with pupal pelts (slide), 21/II/1979, A. Shelley leg. BRAzIL, $R J$, Itatiaia (PN Itatiaia, Riacho abaixo do Lago Azul) 1 female/ exuvia, 3 pupae (spirit), 09/V/1980, A. Luna Dias leg. BraziL, $M G$, Itamonte, 1 larva (slide), 10/II/2003, L. Azevedo \& R. Figueiró leg. BraziL, RJ, Guapimirim, 1 female with pupal pelt (pinned), 06/II/2001, L. Azevedo leg. BrazIL, RJ, Rio de Janeiro (Jacarépagua, Pau da Fome), 1 male (slide), VII/1977, Omar Tavares leg. BrAZIL, RJ, Itaguaí (Sítio Porangaba), 5 pupae (spirit), 10/II/1983, A. Luna Dias leg. BraziL, RJ, Serra da Mantiqueira (Br354 km1), 1 pupa (spirit), 22/V/1979, A. Shelley \& A. Luna Dias leg. BrazIL, RJ, Teresópolis (PARNASO, Córrego Cascatinha), 1 pupa (spirit) (\#1249). INPA: BrazIL, SP, Serra da Bocaina (Fazendo do Bonito), 1 larva (slide) (\#5833), 2 pupae (slide) (\#5832-A, B).

Distribution. Argentina, Misiones (Route 101, 15km Southeast of Deseado); (Parque Nacional do Iguazú, Arroyo Tacuara on Route 101); (15 km Southeast of Eldorado, ruta 101). BrazIL, $B A$, Mucungê (Parque Nacional da Chapada Diamantina). $M G$, Bocaina de Minas (tributary of Rio Preto, between Repouso da Gávea and Pedra da Gávea, 1,440m); Itamonte. PR. Jaguariaiva (Fazenda Serraria Boa Esperança); Morretes (Rio Marumbi). RJ. Angra dos Reis; Rio de Janeiro (Laranjeiras); Teresópolis; Petrópolis; Vassouras; Rio Claro (Getulândia); Duque de Caxias (Xerém); Itatiaia; Guapimirim; Itaguaí; Nova Friburgo. RS. Canela (Arroio Sesi); Maquiné (Rio Maquiné, 900m); São Francisco de Paula (Floresta Nacional de São Francisco de Paula, $29^{\circ} 23^{\prime}-29^{\circ} 27^{\prime} \mathrm{S} 50^{\circ} 23^{\prime}-50^{\circ} 25^{\prime} \mathrm{W}, 850 \mathrm{~m}$ ); Caraá (between 220 and $400 \mathrm{~m}$ ); São Leopoldo (below of $30 \mathrm{~m}$ ); Novo Hamburgo (below of $30 \mathrm{~m}$ ); Santa Cruz do Sul; Três Forquilhas; Turvo; Venâncio Aires; Sapiranga (Picada Verão, Arroio da Mata, tributary of Arroio Feitoria, $\left.29^{\circ} 32^{\prime} \mathrm{S} 51^{\circ} \mathrm{O0}{ }^{\prime} \mathrm{W}\right)$. SC. São Bento do Sul (5 km south of the city). SP. Bragança Paulista; São Paulo (Estrada Velha de Santos); São José do Barreiro (Serra da Bocaina); Salesópolis; Boracéia; Peruíbe (Vale dos Orixás, BR116, Rio Areado); Santa Rosa do Viterbo; Capivari (Estrada de Ferro Oeste de Minas). (Fig. 59).

Remarks. Lutzsimulium hirticosta was described (in Simulium) by LuTz (1909) based on two females of São Paulo city and the types are probably lost. Fortunately, this species is very conspicuous and has been collected many times in many different localities, so the identity was not lost with its types. LuTz (1910) using further material from other localities described male, pupa and lava. D'ANDRETTA JR \& Vulcano (1947) proposed Lutzsimulium to include the new species Lutzsimulium cruzi. Later $L$. cruzi was considered junior synonym of $L$. hirticosta (VULCANo 1967) which was kept as type species of Lutzsimulium. Following the Code recommendation (ICZN, 1999), it is not necessary to designate a neotype for the species, that descriptions and material firmly fix the name. However, it should be noted that the allotype of $L$. cruzi is invalid, because it was designed after the creation of the name.
Biological and distributional notes. This species has a wide distribution, stretching from northeastern Brazil to northwestern Argentina. But its occurrence is punctual and always few numbers of specimens are collected, suggesting a restricted habitat preference associated with variables still unknown. There seems to be no relation between the occurrence of $L$. hirticosta and the altitude, since the species was found at different heights. On the other hand, there is an association of this species with small creeks within rainforest areas with low anthropic impact.

\section{Lutzsimulium pernigrum (Lutz, 1910)}

\section{Figs 34-41}

Simulium montanum (not Phillipi, 1865, misidentification): Lutz (1909):132, 134-135. Surcouf \& Gonzalez-Rincones (1911): 289-290. Pinto (1930): 481-482. Amaral-Calvão \& MaiaHerzog (2003): 265, 267.

Simulium pernigrum: Lutz (1910): 226, 261, 263, 265-266 figs 19, 20. Knab (1911): 179. Pinto (1930): 477, 482. Pinto (1932): 708, 726-727, 756. Smart (1945): 511. Vargas (1945): 181. Eusimulium pernigrum: Lane \& Porto (1939): 169. Simulium (Friesia) pernigrum: Rubtsov (1940): 124. Lutzsimulium pernigrum: Vulcano \& D'Andretta Jr (1952): 311-323, figs 149. Vulcano (1962): 240-244. Vulcano (1967): 16.4. Forattini et al. (1971): 359. Wygodzinsky \& Coscarón (1973): 196-197, figs 43 A-T. Vulcano (1977): 291. Vulcano (1981): 276. PyDaniel (1981): 174. Py-Daniel (1982): 304-305, 311-312, figs 13 A, 14 A-B. Coscarón (1991): 81-82, figs 16 K-N. Py-Daniel \& Sampaio (1994): 112. Py-Daniel \& Sampaio (1995): 119. Strieder (2002): 131, 133, 135-136. Strieder et al. (2002): 534537. Amaral-Calvão \& Maia-Herzog (2003): 262, 265-268. Pepinelli et al. (2003): 654. Strieder (2004): 117. Gil-Azevedo et al. (2005b): 743, 746. Figueiró et al. (2006): 544-549. Pepinelli et al. (2006): 699, 701, 703. Coscarón \& Coscarón-Arias (2007): 104-106, 108-109, figs 24 K-N. Gil-Azevedo \& Maia-Herzog (2007): 41, 43, 51, 66. Coscarón et al. (2008): 11. Shelley et al. (2010): 19, 52, 77, 159-162, 596, figs 55, 77-78, 83, 167, 252253, 425, 504, 587, 671, 754-755, 908, 989, 1067, 1143-1144. Gil-Azevedo \& Maia-Herzog (2010): 350. Lutzsimulium (Lutzsimulium) pernigrum: Crosskey \& Howard (1997): 16. Crosskey \& Howard (2004): 7. Adler \& Crosskey (2008): 23. Adler \& Crosskey (2009): 24. Adler \& Crosskey (2010): 24.

Types. - LECTOTYPE: LUTZ-IOC 12,249 + 12,250, BraZIL, SP, Serra da Bocaina, female (in 2 slides). PARALECTOTYPES: LUTZIOC, BraZIL, SP, Serra da Bocaina, 2 adults (pinned), 441; 3 adults (pinned), 442; 2 adults (pinned), 443; 3 adults (pinned), 444. The allotype MZSP 50 male (in 3 slides) is invalid.

Description. Female. General body color black. Body length 2.6-3.1 mm $(\mathrm{n}=2)$; mesothorax length $1.3-1.5 \mathrm{~mm}$, mesothorax width 0.9-1.1 $\mathrm{mm}(\mathrm{n}=5)$; wing length $2.8-3.3 \mathrm{~mm}$, wing width 1.4-1.6 mm ( $\mathrm{n}=5)$. Head, nudiocular, frons, clypeus, occiput and antennae as L. flavopubescens (Fig. 3). Except clypeus 

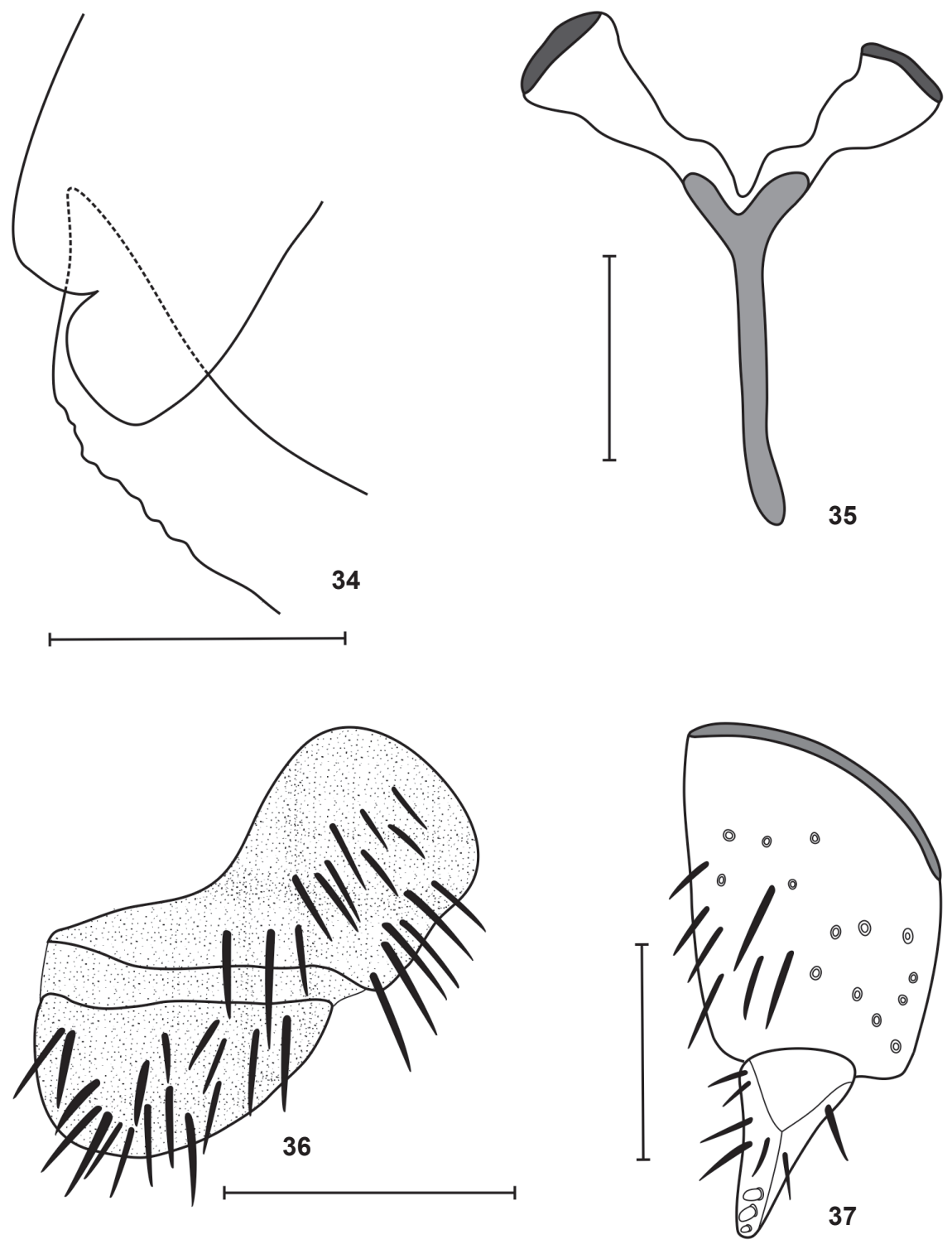

Figure 34-37. Adult of L. pernigrum: (34-36 female) (34) calcipala and pedisulcus; (35) genital fork; (36) cerci and paraproct. (37) male, gonocoxite and gonostylus. Bar: $0.1 \mathrm{~mm}$.

longer than wide. Mouthparts coloration as L. flavopubescens. Mandible with about 38 teeth on internal side, without teeth on external side. Maxilla with about 14 teeth each side; palp with the last and the penultimate palpomeres approximately equal; Lutz's organ length about $1 / 6$ of basal article length. Cibarium as L. flavopubescens (Fig. 4). Scutum, postpronotal lobe, scutellum, postnotum, and pleural region as $L$. flavopubescens. Medium arms of furcasternum with projections (Fig. 5). Chaetotaxy of wing veins and halteres coloration as $L$. flavopubescens. Legs as L. flavopubescens, calcipala and pedisulcus
(Fig. 34). Abdomen as L. flavopubescens. Hypogynial valve (Fig. 9), genital fork (Fig. 35), and spermatheca (Fig. 12) as $L$. flavopubescens. Cerci and paraproct shape as L. flavopubescens; paraproct longer than cerci (Fig. 36).

Male. General body color black. Body length 2.1-3.1 mm $(\mathrm{n}=3)$; mesothorax length $1.0-1.3 \mathrm{~mm}$, mesothorax width 0.8 $1.0 \mathrm{~mm}(\mathrm{n}=5)$; wing length $2.7-3.1 \mathrm{~mm}$, wing width $1.2-1.4$ $\mathrm{mm}(\mathrm{n}=4)$. Head holoptic with black reddish eyes. Frons, clypeus, mouthparts, occiput and antennae colorations as in female. Lutz's organ length about $1 / 6$ of basal article length. 

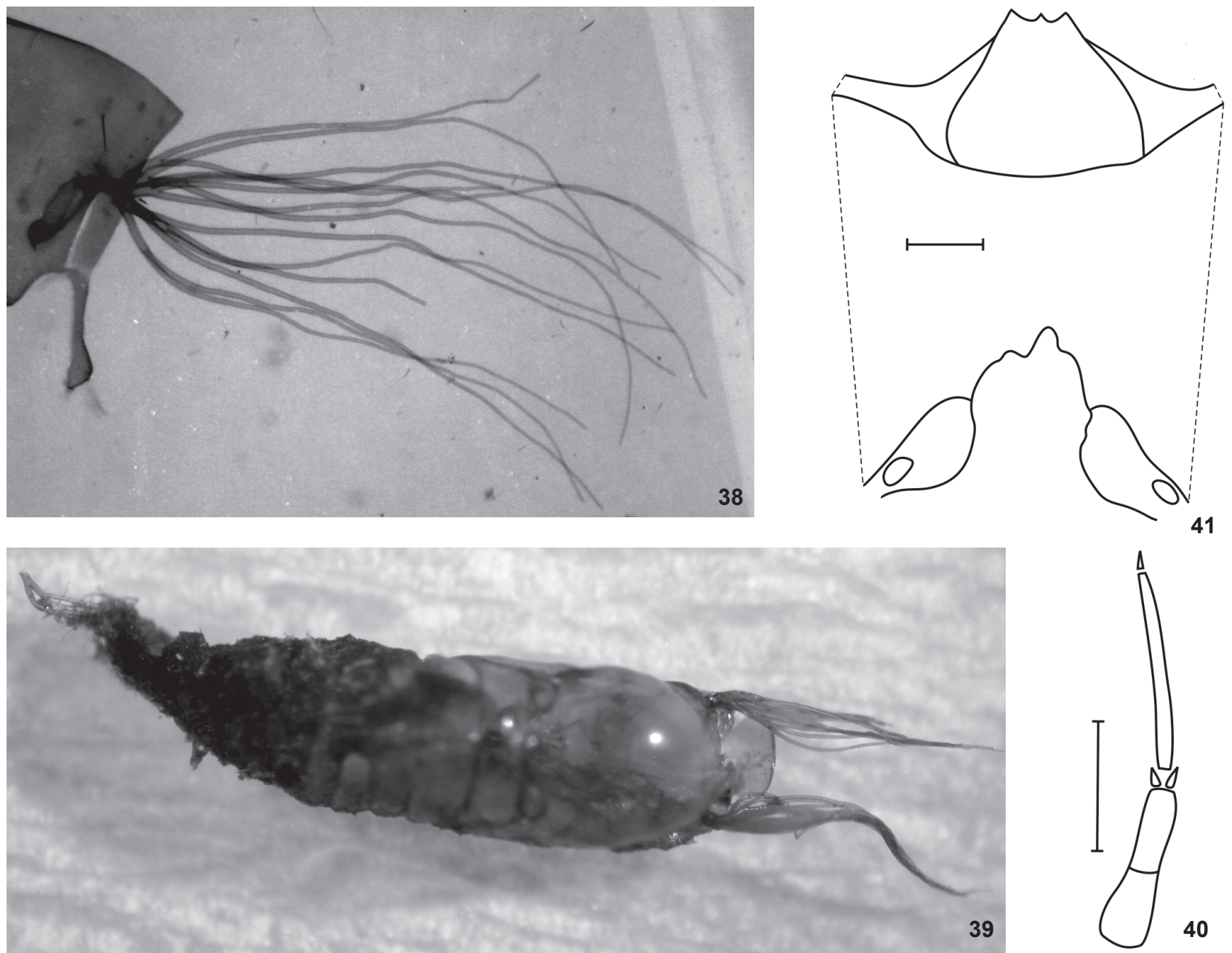

Figure 38-41. Immatures of L. pernigrum: (38-39 pupa) (38) gill; (39) pupa and cocoon. (40-41 larva) (40) antenna; (41) head capsule, ventral view. Bar: $0.1 \mathrm{~mm}$.

Thorax coloration, furcasternum, wing veins, halteres coloration, and legs as in female. Abdomen as in female. Gonocoxite (Fig. 37) and gonostylus as L. flavopubescens; gonostylus apex with two or three developed spinules ( 1 apical +1 or 2 subapical) (Fig. 37). Ventral plate and gonostylus similar sized. Ventral plate (Figs 14 and 15) and median sclerite (Fig. 16) as $L$. flavopubescens. Paramere and dorsal plate absent.

Pupa. Length 3.2-3.6 mm ( $\mathrm{n}=10)$; gill length 1.4-1.8 $\mathrm{mm}(\mathrm{n}=10)$. Gill with 14 gill filaments branching in a dichotomous way (arborescent) and directed forward (Fig. 38); the basal stalk immediately giving rise to two main trunk with six and eight filaments $[(2+2)+(2+2)]+[2+(2+2)]$ (Fig. 38); filaments as $L$. flavopubescens. Head and thorax surface light cracked and without tubercles; head and thorax chaetotaxy as L. flavopubescens. Abdomen, abdominal chaetotaxy, and cocoon (Fig. 39) as L. flavopubescens.
Larva (final instar). General coloration light brown. Maximum length 6.9-7.1 mm $(\mathrm{n}=10)$; head capsule dorsal length 0.8-0.9 $\mathrm{mm}$ and dorsal width $0.7 \mathrm{~mm}(\mathrm{n}=10)$; gill histoblast length, in situ $0.4 \mathrm{~mm}$ and width $0.3 \mathrm{~mm}(\mathrm{n}=10)$. Head capsule pattern (in dorsal view) and cervical sclerites as $L$. flavopubescens (Fig. 20). Head capsule without setae. Antennae as $L$. flavopubescens, except medial article longer than proximal, but lesser than twice (Fig. 40). Stalk of labral fan distinctly longer than antennae; labral fan with 36-42 rays. Mandibular teeth, 1 apical, 2 external, 2 subapical, about 12 internal teeth and 2 mandibular serration. Hypostoma and hypostomal teeth as L. flavopubescens (Fig. 22). Postgenal cleft shape as $L$. flavopubescens (Fig. 41); postgenal bridge longer than hypostoma (Fig. 41). Subesophageal ganglion slightly pigmented. Thorax and abdomen as L. flavopubescens, except anal ring with about 76 rows of about 13-15 hooks each. 
Examined material. MLP: BrazIL, RS, Canela, 1 female and 1 male with pupal pelts (slide), 07/XI/1981, S. Coscarón leg. BraziL, RJ, Itatiaia, 1 pupa (slide), 24/I/1948, C. d'Andretta leg. Argentina, Corrientes ( $4^{\text {to }}$ Ao. hasta Galarza), 1 pupa (slide), 13/ VIII/00, S. Coscarón leg. LUTZ-IOC: BRAZIL, SP (Serra da Bocaina, Fazenda do Bonito), 1 female (slide), 7 pupae (slide) \# 12249, 12250, 12246, 12247, 12248, 12251, 12252, 12253, 12254. LSOIOC: BrazIL, SP, Campos do Jordão, 3 pupae and 3 larvae (spirit) \#017. Campos do Jordão (Parque Estadual), 1 female with pupal pelts (pinned), 17/10/1979, A. Shelley \& A. Luna Dias leg. Brazil, SP (Serra da Bocaina, Fazenda do Bonito), 4 female and 3 male with pupal pelts (pinned), 2 female with pupal pelt (slide), 05-06/IV/1978, A. Shelley leg. BrazIL, RJ (Br. 354 km 4), 1 male with pupal pelt (slide), 22/V/1979, A. Shelley leg., BrAZIL, MG, Itamonte, 2 larvae (slide), 10/II/2003, L. Azevedo \& R. Figueiró leg. BraziL, $S P$, Campos do Jordão, 1 female and 1 male with pupal pelt (pinned), 17/X/1979, A. Shelley \& A. Luna Dias leg. BraziL, SP (Serra da Bocaina, Fazenda do Bonito), 1 female, 1 male, 2 pupae (slide), 05/IV/1978, A. Luna Dias leg. BrazIL, $M G$ (between W. Brás and Delfim Moreira), 1 female with pupal pelts (pinned) \#1248; BrAZIL, MG (Br 459, km 28), 1 male with pupal pelts (pinned) \#1247. BrazIL, MG ( $\mathrm{km} \mathrm{28,} \mathrm{Br} \mathrm{459),} 1$ male with pupa pelts (pinned), 19/V/1979, A. Shelley \& A. Luna Dias leg. INPA: [?] 1 pupa (slide).

Distribution. Argentina, Corrientes, Galarza. BraziL, MG, Bocaina de Minas (Rio Preto, boundary between RJ and MG, 1,370m); Itamonte (Parque Nacional do Itatiaia, Brejo da Lapa); Marmelópolis (Marmelópolis stream at Fazenda Sariqui, $22^{\circ} 30^{\prime} \mathrm{S}$ $45^{\circ} 09^{\prime} \mathrm{W}$ ). RJ. Petrópolis; Itatiaia (Riacho Água Chorada, 2,100 $\mathrm{m})$; (Macieiras, 1,800 m); (Planalto, 2,200 m); (Três Picos). $R S$. Canela (Arroio Sesi); Maquiné (Rio Maquiné, 900m); São Francisco de Paula (Floresta Nacional de São Francisco de Paula, $\left.29^{\circ} 23^{\prime}-29^{\circ} 27^{\prime} \mathrm{S} 50^{\circ} 23^{\prime}-50^{\circ} 25^{\prime} \mathrm{W}, 850 \mathrm{~m}\right)$. SP. São José do Barreiro (Serra da Bocaina); Campos do Jordão. (Fig. 60).

Remarks. The material collected by Lutz from Serra da Bocaina, SP was first identified as Simulium montanum Phillipi, 1865, a species from the extreme south of South America (LuTz 1909). One year later he changed his mind and described the material (female, male, pupa and larva) as a new species (LuTz 1910). But after that, some confusion in the literature still remained (Surcouf \& Gonzalez-Rincones 1911; Pinto 1930; AmaralCalvão \& Maia-Herzog 2003). Vulcano \& D’Andretta Jr (1952) transferred this species to Lutzsimulium, redescribed all stages, designated lectotype and paralectotypes based in the Lutz types (females), and also designated an invalid allotype. Figueiró et al. (2006) registered L. pernigrum from Agulhas Negras, RJ, but probably that was a misidentification because it was based on immature larvae, and in posterior collects only L. flavopubescens was found in this area.

Biological and distributional notes. This species has a wide distribution, from Southeastern Region of Brazil to northwestern Argentina. But its occurrence is restricted, and there is a strong relation between the presence of the species and the altitude/latitude. In southeastern Brazil (between $22^{\circ} 10^{\prime}-22^{\circ} 44^{\prime} \mathrm{S}$ range) the altitudes recorded for the species are around $2,000 \mathrm{~m}$, in southern Brazil (between $29^{\circ} 21^{\prime}-29^{\circ} 40^{\prime} \mathrm{S}$ range) the altitudes recorded are about $1,000 \mathrm{~m}$, and in Corrientes, Argentina (about $28^{\circ} 06^{\prime} \mathrm{S}$ ) the altitude of the single record is at sea level. But this last record is doubtful, because only one pupa was found among a lot of A. iberaensis, and more collecting is necessary in the locality to confirm it. Anyway, this species is probably related to relicts of Araucaria Forests (Araucaria angustifolia), but more studies are necessary to confirm it. Like L. hirticosta, L. pernigrum is associated with small creeks with low anthropic impact, but unlike the first, it is possible to collect large numbers of $L$. pernigrum specimens.

\section{Lutzsimulium simplicicolor (Lutz, 1910)} Figs 42-57

Simulium simplicicolor: Lutz (1910): 251-253, 262, 264-265, figs 37, 43. Knab (1911): 179. Neiva \& Penna (1916): 93. Lutz (1922): 90. Pinto (1930): 481. Pinto (1932): 712, 725, 756. Fairchild (1940): 706. Smart (1945): 513. Vargas (1945): 197. Floch \& Abonnenc (1946): 8. Cerqueira (1967): 127-128, 133 134. Vulcano (1967): 16.20. Vulcano (1977): 293. Lacey \& Charlwood (1980): 497-506. Lacey (1981): 330. Vulcano (1981): 277. Lutzsimulium simplicicolor: Py-Daniel (1979): 785, fig. 1C. Py-Daniel (1981): 174. Amaral-Calvão \& Maia-Herzog (2003): 267-268. Shelley et al. (2010):19, 52, 77, 162-166, 596, figs $51,58,84,168,254-255,426,505,588,672$, 756-757, 909, 990, 1068, 1145-1146. Eusimulium simplicicolor: Surcouf \& Gonzalez-Rincones (1911): 286. Kempfsimulium simplicicolor: Py-Daniel, 1982: 300-307, 312, figs "Mapa 1", 1 A-M, 2 N-V, 3 A-C, 4 A-L, 5 A, 6 A-G, 7 H-L, 8 M-P, 9 A-D, 10 A-K, 11 L-P, 12 A. Py-Daniel \& Sampaio (1994): 111. Py-Daniel \& Sampaio (1995): 119. Coscarón \& Coscarón-Arias (2007): 111114, figs 26 A-Q, 27 A-K. Gil-Azevedo \& Maia-Herzog (2007): 41, 43, 47, 49-51, 54, 58, 66, fig. 3E. Coscarón et al. (2008): 10. Lutzsimulium (Kempfsimulium) simplicicolor: Crosskey \& Howard (1997): 16. Crosskey \& Howard (2004): 7. Adler \& Crosskey (2008): 23. Adler \& Crosskey (2009): 24. Adler \& Crosskey (2010): 24 .

Simulium hebeticolor (typographic error): Lutz (1910): 267.

Types. LECTOTYPE = LUTZ-IOC 12686-A, BRAZIL, RO, Rio Madeira, 1female pinned, 27/IX/1910. PARALECTOTYPES = LUTZIOC, BRAZIL, RO, Rio Madeira, 27/IX/1910, 12,682-A (5 females pinned), 12,682-B (4 females pinned), 12,682-C (5 females pinned), 12,683-A ( 4 females pinned), 12,683-B ( 2 females pinned), 12,683-C ( 2 females pinned), 12,683-C ( 2 females pinned), 12,683-D (3 females pinned), 12,684-A (4 females pinned), 12,684-B (3 females pinned), 12,684-C ( 2 females pinned), 12,685-A (4 females pinned), 12,685-B (4 females pinned), 12,685-C (5 females pinned), 12,686-B (5 females pinned), 12,686-C (3 females pinned), 12,686-D (3 females pinned), 12,687-A (4 females pinned), 12,687-B (5 females 

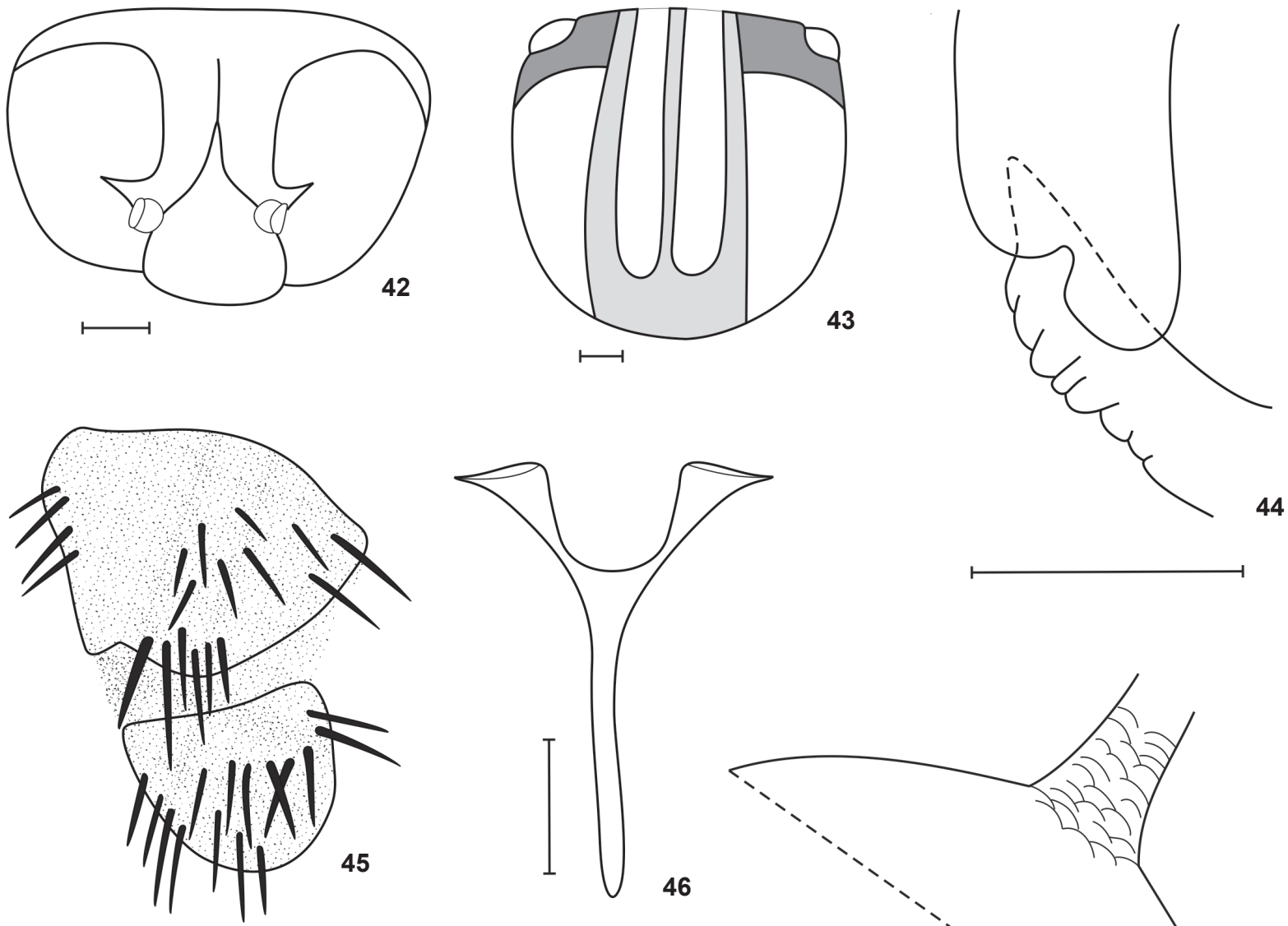

43
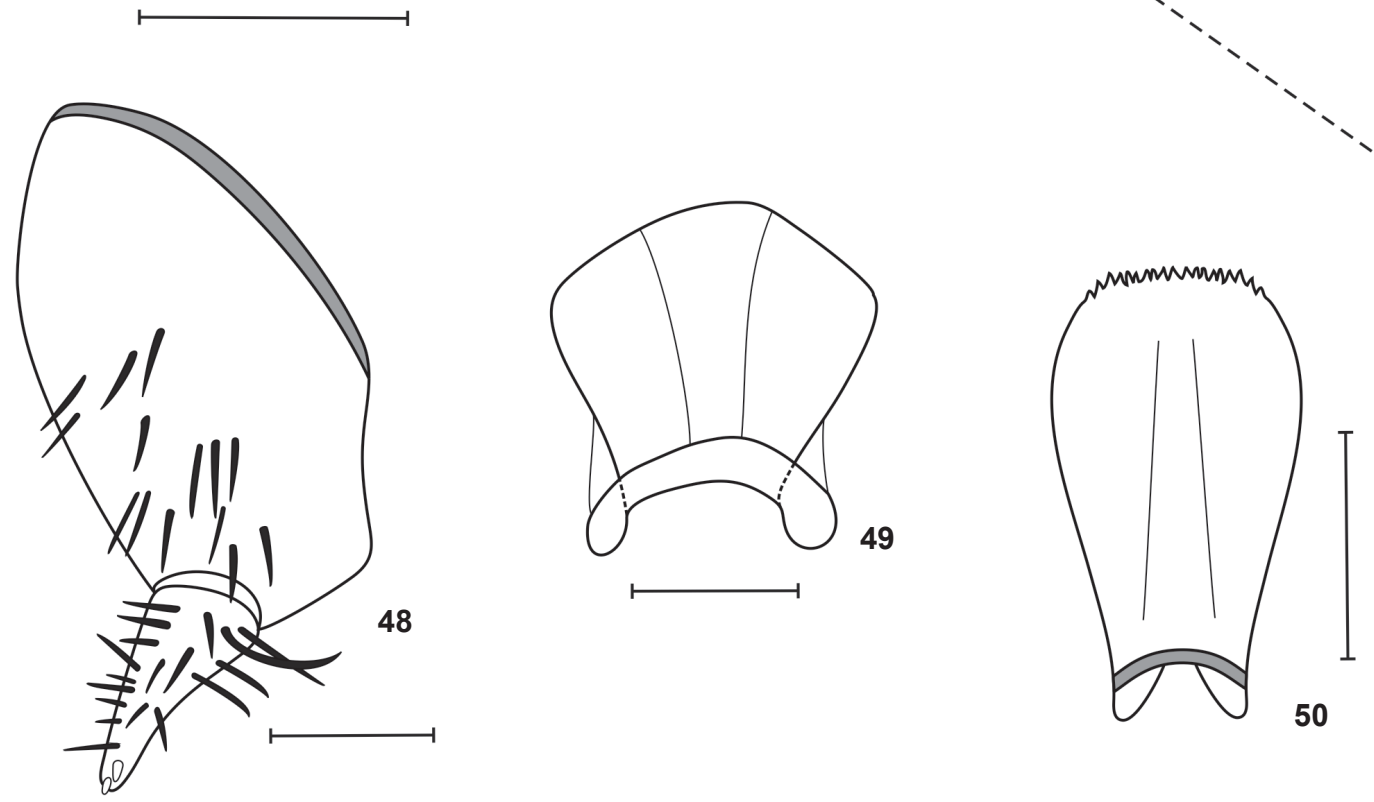

Figure 42-50. Adult of L. simplicicolor: (42-47 female) (42) head; (43) thorax; (44) calcipala and pedisulcus; (45) cerci and paraproct; (46) genital fork; (47) spermatheca. (48-50 male) (48) gonocoxite and gonostylus; (49) ventral plate, dorsal view; (50) median sclerite. Bar: $42-43=1.0 \mathrm{~mm}, 44-50=0.1 \mathrm{~mm}$. 

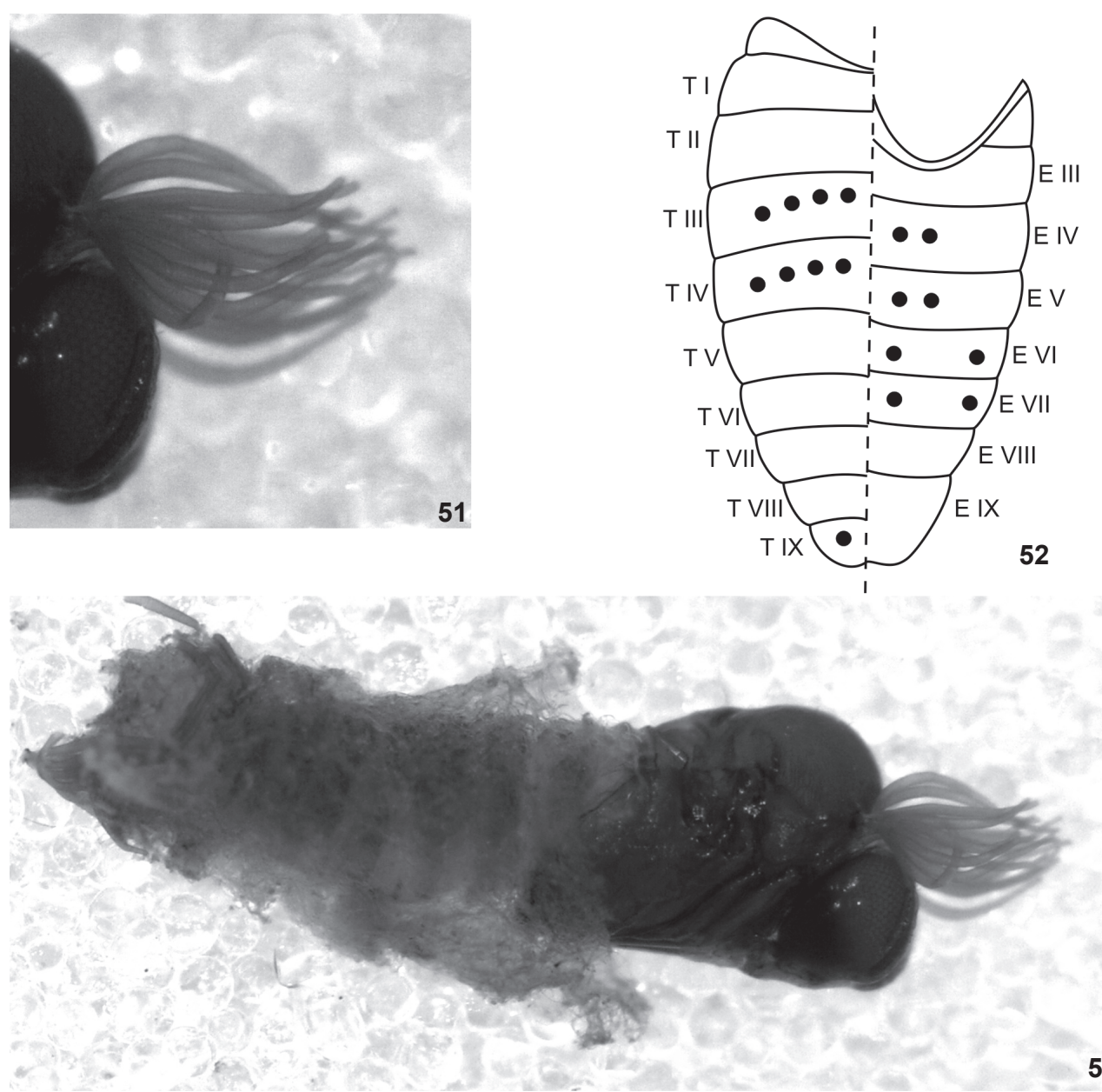

53
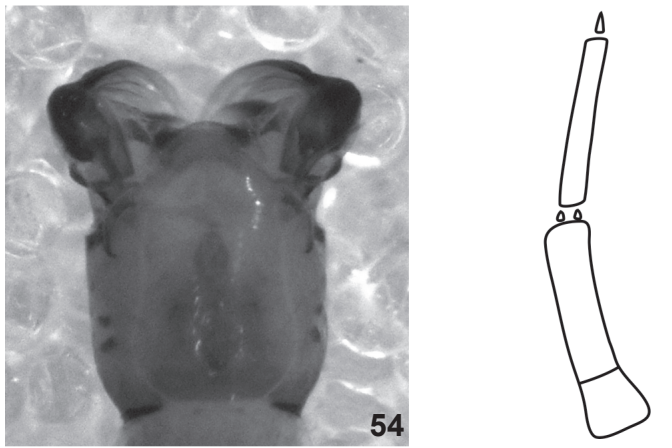

55
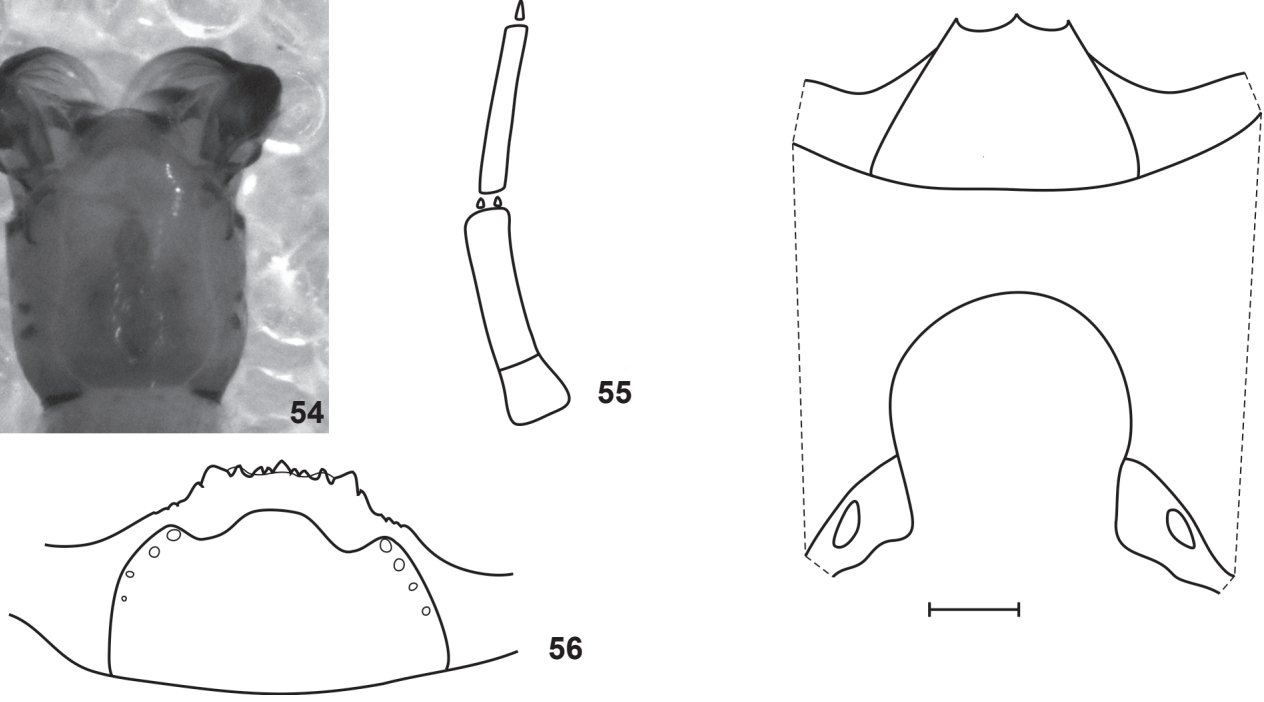

57

Figure 51-57. Immature of L. simplicicolor: (51-53 pupa) (51) gill; (52) abdominal chaetotaxy; (53) pupa and cocoon. (54-57 larva) (54) head capsule, dorsal view; (55) antenna; (56) hypostomal teeth; (57) head capsule, ventral view. Bar: $0.1 \mathrm{~mm}$. 
pinned), 12,688-A (4 females pinned), 12,688-B (4 females pinned), 12,689-A (3 females pinned), 12,689-B (3 females pinned), 12,690-A (2 females pinned), 12,690-B (3 females pinned), 12,691-A (1 female pinned), 12,691-B (4 females pinned), 12,692-A (4 females pinned), 12,692-B (3 females pinned), 12,323 (females slide), 12,324 (3 females slide).

Description. Female. General body color orange. Body length 2.4-2.6 mm $(\mathrm{n}=3)$; mesothorax length 1.2-1.3 mm, mesothorax width 0.9-1.0 $\mathrm{mm}(\mathrm{n}=3)$; wing length 2.8-3.0 mm, wing width $1.1-1.3 \mathrm{~mm}(\mathrm{n}=3)$. Head, eyes and nudiocular area as $L$. flavopubescens. Frons, clypeus and occiput brownish black with silver pruinosity and many long copper bristles; frons higher than wide and with a medial suture (Fig. 42), clypeus longer than wide and with acute apex, distinctly developed in relation of other species of the genus (Fig. 42). Antennae with silver pruinosity; scape and pedicel yellow, flagellomeres black. Mouthparts dark, except labrum and basal article of palp yellow, and with copper bristles. Mandible with about 35 teeth on internal side, without teeth on external side. Maxilla with about 15 teeth each side; palp with the last palpomere larger than penultimate; Lutz's organ length about $1 / 3$ of basal article length. Cibarium as $L$. flavopubescens (Fig. 4). Scutum orange with softly marked pattern, $1+1$ light brown areas in anterior scutum and three light grey strips (Fig. 43). Postpronotal light brown. Scutum and postpronotal with silver pruinosity and many copper bristles uniformly distributed. Scutellum greyshed light yellow with silver pruinosity and many long black bristles. Postnotum and pleural region orange with silver pruinosity. Medium arms of furcasternum with projections (Fig. 5). Chaetotaxy of wing veins as L. flavopubescens. Halteres mostly dark brown, apex yellow. Legs as L. flavopubescens, calcipala and pedisulcus (Fig. 44). Abdomen as L. flavopubescens. Hypogynial valve as $L$. flavopubescens (Fig. 9). Cerci shape as $L$. flavopubescens; paraproct small, trapezium-shape, with digitlike projection in the anterior and basal area, without a tail; paraproct longer than cerci (Fig. 45). Genital fork as $L$. flavopubescens, except it is entirely unpigmented (Fig. 46). Spermatheca spherical; spermatheca entirely pigmented; only surface of the spermathecal duct with net-like structure (Fig. 47).

Male. General body orange. Body length 3.4-4.1 mm $(\mathrm{n}=3)$; mesothorax length 1.0-1.2 mm, mesothorax width 0.9$1.0 \mathrm{~mm}(\mathrm{n}=5)$; wing length $2.3-2.6 \mathrm{~mm}$, wing width $1.2-1.3$ $\mathrm{mm}(\mathrm{n}=2)$. Head holoptic with black reddish eyes. Frons, clypeus, mouthparts, occiput and antennae colorations as in female. Lutz's organ length about 1/4 of basal article length. Thorax coloration, furcasternum, wing veins, halteres coloration, and legs as in female. Abdomen as in female. Gonocoxite large, length longer than the gonostylus; gonocoxite with trapezium shape, that the right side is smaller than the left, and the greater width and the greater height sub-equal; gonocoxite of this species more rounded than the other species of Lutzsimulium (Fig. 48). Gonostylus as L. flavopubescens; gonostylus apex with two developed spinules (apical + sub- apical) (Fig. 48). Ventral plate hemispheric with sclerotized basal arms, medium area high, lateral margins concave in the middle and distinctly pointed in the distal area, and concave pointed apex; the ventral plate is very faintly (Fig. 49). Ventral plate longer than gonostylus. Median sclerite elongated and flattened; rectangle shape with rounded lateral sides (Fig. 50). Paramere present and developed, with small spines in the apex; dorsal plate absent.

Pupa. Length 3.0-3.8 mm $(\mathrm{n}=10)$; gill length 1.1-1.3 $\mathrm{mm}(\mathrm{n}=10)$. Gill with 12 gill filaments branching in a dichotomous way (arborescent) and directed forward (Fig. 51); the basal stalk immediately giving rise to two main trunk each with about six (Fig. 51); all filaments with equal length and width; surface of gill filaments smooth; apex of all filaments digit-like; filaments shorter and thicker than the filaments of the others Lutzsimulium (Fig. 51). Head surface light cracked and thorax surface smooth, both without tubercles; head and thorax chaetotaxy as $L$. flavopubescens, except by the absence of sexual dimorphism, with $2+2$ frontal trichomes in male and female. Abdomen as L. flavopubescens. Abdominal chaetotaxy as L. flavopubescens, except sternite IV with 2+2 hooks (Fig. 52). Cocoon as $L$. flavopubescens, except cocoon covering abdomen and part of thorax (Fig. 53).

Larva (final instar). General coloration light brown. Maximum length 7.0-8.1 mm ( $\mathrm{n}=10)$; head capsule dorsal length 0.7-0.9 $\mathrm{mm}$ and dorsal width 0.6-0.7 $\mathrm{mm}(\mathrm{n}=10)$; gill histoblast length, in situ $0.5 \mathrm{~mm}$ and width $0.4 \mathrm{~mm}(\mathrm{n}=10)$. Head capsule pattern (in dorsal view) and cervical sclerites as $L$. flavopubescens (Fig. 54). Head capsule without setae. Antennae with all articles unpigmented; proximal article broad and short; medial article longer than proximal; distal article thin and equal length than proximal + medial (Fig. 55). Stalk of labral fan distinctly longer than antennae; labral fan with 46-51 rays. Mandibular teeth, 1 apical, 2 external, 2 subapical, about 12 internal teeth and 2 mandibular serration. Hypostoma and hypostomal teeth as L. flavopubescens, except hypostoma with $1+1$ reduced paralateral teeth (Fig. 56). Postgenal cleft shape as L. hirticosta (Fig. 57); hypostoma longer than postgenal bridge (Fig. 57). Subesophageal ganglion slightly pigmented. Thorax and abdomen as $L$. flavopubescens, except anal sclerite ventral and dorsal arms similar sized (Fig. 33); and anal ring with about 115 rows of 24-26 hooks each.

Examined material. INPA: BrazIL, Rondônia: Rio Madeira (Cachoeira Girau) 4 females (spirit), 20/III/2004, J. Oliveira leg.)]; Porto Velho (Rio Madeira, Cachoeira Caripuana), 5 pupae and 5 larvae (spirit), 22/III/04, N. Hamada leg.; Porto Velho (Rio Caracol, Cachoeira Rio Bonito), 5 pupae and 5 larvae (spirit), 1 male (pinned), 30/III/04, 14/VI/04, N. Hamada leg. [?] 1 larva (slide), 4 pupae (slide) (\# 5,478, 5,530, 5,302, 5,302-17]. MLP: BraziL, Pará: Cachimbo, 1 female and 3 males (slide), 06/14/VI/ 1956, Travassos \& Adão leg. [C.7] 1 male with pupal pelt (slide). Mato Grosso: Aripuanã (Dardanelos), 1 larva (slide), 29/V/1978, E. Silva leg.)]. LUTZ-IOC: BraziL, RO, Rio Madeira, 3 females 
(slide), 27/IX/1910 (\# 12,324). LSO-IOC: BRAzIL, Rondônia: Rio Madeira, 3 females, 5 males, 5 pupas and 5 larvae (spirit), 2 females, 4 males, 2 pupae and 3 larvae (slide) (\# 021); Rio Madeira, 3 females (pinned) (\# 001); (Estrada de Ferro MadeiraMamoré), 1 female (slide), O. Tavares leg.)].

Distribution. BrazIL, MT, Aripuaña (Humboldt Research Facility, $10^{\circ} 11^{\prime} \mathrm{S} 59^{\circ} 49^{\prime} \mathrm{W}, 250 \mathrm{~m}$ ); (Igarapé dos Porcos, tributary Rio Aripuanã); (Dardanelos). PA. Novo Progresso (Serra do Cachimbo, 400 m); (Road Cachimbo-Santarém); Itaituba (Parque Nacional da Amazônia - Tapajós, Igarapé da Montanha); Itaituba (PNA, Igarapé Mambuaí), (PNA, Cachoeira da Terra); (PNA, Igarapé Mambuaizinho); São Félix do Xingu (Reserva Florestal de Gorotire, Funai/IBDF, Rio Fresco, tributary of the Rio Xingú); (Kuben-Kran-Kein). RO. Porto Velho (Estrada de Ferro MadeiraMamoré); (Rio Jaciparaná, harbor); (Igarapé do Burrinho, tributary of the Rio Jaciparaná); (Rio Madeira, Cachoeira do Teotônio); (Rio Novo, tributary of the Rio Jamarí, Br.364, between Porto Velho and Ariquemes). (Fig. 58).

Remarks. This species was described by LuTz (1910) from material collected during the construction of Madeira-Mamoré Railway, Rondônia, Brazil. Females were found biting the workers in many localities of the railway, and some pupae and larvae were collected in some streams next to the railway. Later, Lutz's immatures of L. simplicicolor were identified as Simulium rorotaense Floch \& Abonnenc by Py-Daniel and the true immatures of L. simplicicolor were described (Py-Daniel 1982).
But before that, the species identity was nebulous and much confusion occurred in the literature, such as misidentification of pupae (Fairchild 1940; Floch \& Abonnenc 1946; Cerqueira 1967), and very doubtful records of females (Neiva \& Penna 1916; Lacey 1981). Py-Daniel $(1979,1981)$ proposed the transfer of this species to Lutzsimulium without explanation. But one year later he decided (with Nunes de Mello) to create Kempfsimulium to place the species, providing an exhaustive study about it, description of male, pupa and larva, and redescription of female, and a comparison of his new genus with other genera (Py-Daniel 1982).

Biological and distributional notes. The species is found in the southern and eastern borders of Brazilian Amazonia. The immatures occur in Amazonian streams inside the forest (Igarapés) (Py-Daniel 1982). Females were collected biting horses, cows, monkeys, and humans (Py-Daniel 1982).

The species was originally considered a human pest, because bites were a problem during the construction of the railway Madeira-Mamoré (LuTz 1910). But, in almost one century, only one study was carried out on the anthropophilylic habits of the species (Lacey \& CHarlwood 1980), In spite of the fact that it considered anthropophilic, and is present in a region next to the Amazonian focus of onchocerciasis (SHelley et al. 1997), and given the possibility of expansion of the disease (SHelLey et al. 2000), very little is known about the biology of this species (Py-Daniel 1982).

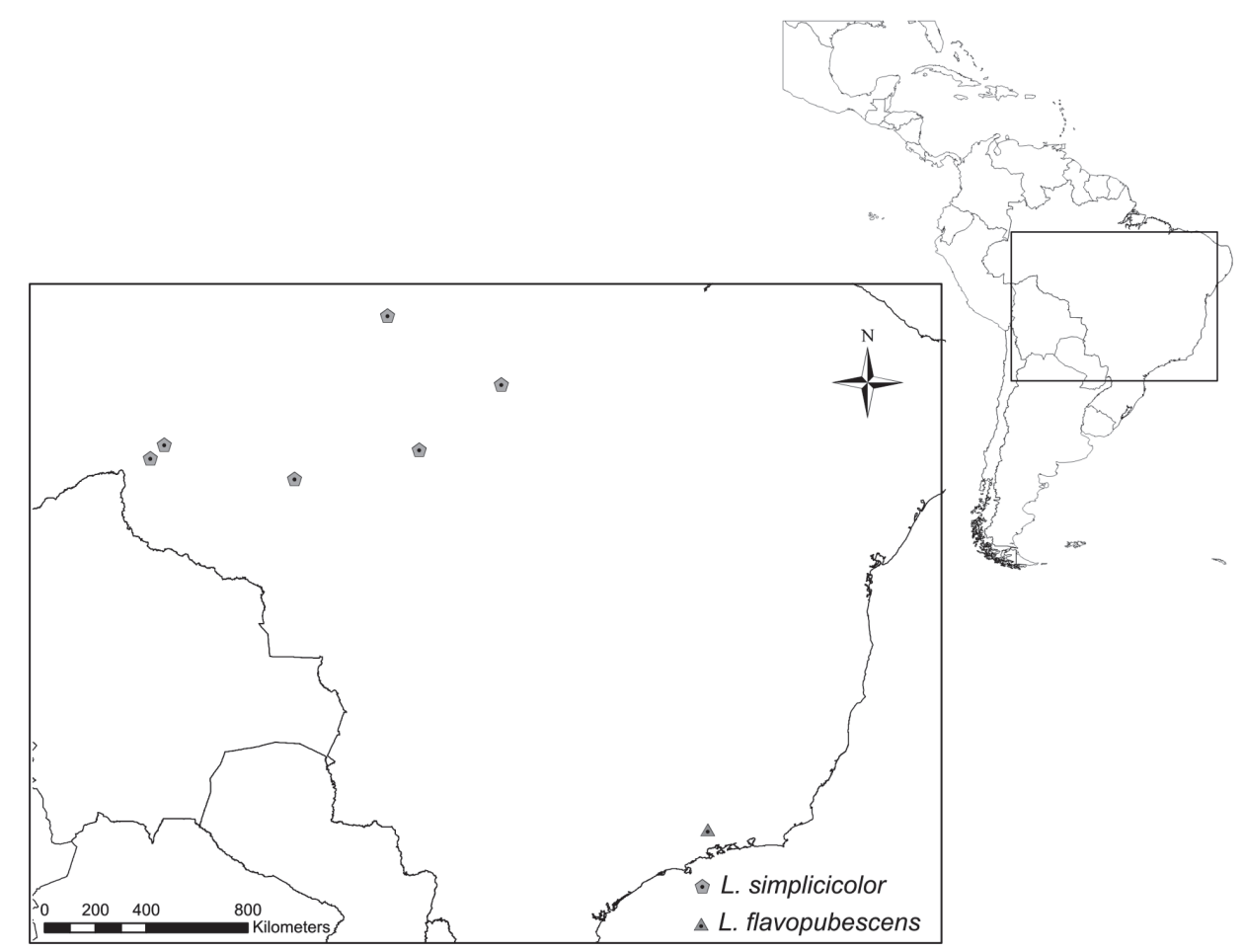

Figure 58. Distribution map of L. flavopubescens and L. simplicicolor. 

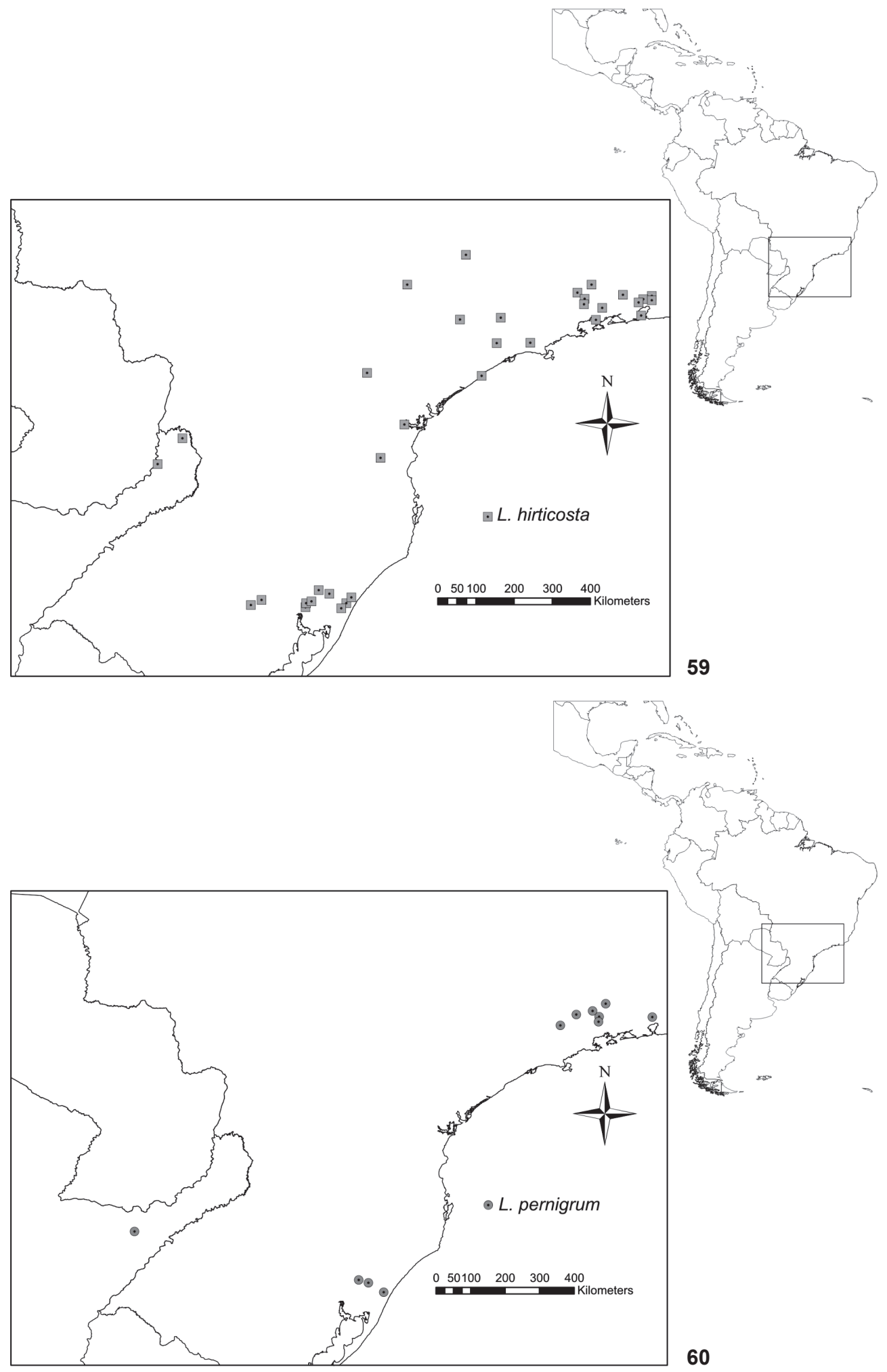

Figures 59-60. Distribution map of L. hirticosta (59) and L. pernigrum (60). 


\section{ACKNOWLEDGEMENTS}

Sixto Coscarón (MLP), Neusa Hamada and Victor Py-Daniel (INPA) kindly permitted access to their respective collections and donated additional material. Amanda Mendes (MN-UFRJ), Sixto Coscarón (MLP) and anonymous referees contributed many thoughtful suggestions that improved this work. Guilherme Herzog (UFF) and Adriano Kury (MN-UFRJ) reviwed the English. I also thank Nelson Ferreira Jr (IB-UFRJ) and Marilza Maia-Herzog (IOC-FIOCRUZ) for being my advisors during this research. The results of this research are part of the author's thesis as a requisite for obtaining a PhD degree in Biological Sciences (Zoology) at the Museu Nacional, UFRJ. This research was sponsored by a scholarship granted to the author by the CNPq.

\section{LITERATURE CITED}

Adler, P.H. \& R.W. Crosskey. 2008. World blackflies (Diptera: Simuliidae): a fully revised edition of the taxonomic and geographical inventory. Clemson, Clemson University. Avaliable online at: http://entweb.clemson.edu/biomia/ pdfs/blackflyinventory.pdf [Accessed: 14/X/2008].

Ader, P.H. \& R.W. Crosskey. 2009. World blackflies (Diptera: Simuliidae): a comprehensive revision of the taxonomic and geographical inventory. Clemson, Clemson University. Avaliable online at: http://entweb.clemson.edu/biomia/ pdfs/blackflyinventory.pdf [Accessed: 5/X/2009].

Adler, P.H. \& R.W. Crosskey. 2010. World blackflies (Diptera: Simuliidae): a comprehensive revision of the taxonomic and geographical inventory. Clemson, Clemson University. Avaliable online at: http://entweb.clemson.edu/biomia/ pdfs/blackflyinventory.pdf [Accessed: 25/VII/2010].

Adler, P.H.; Currie, D.C. \& D.M Wood. 2004. The Black Flies (Simuliidae) of North America. New York, Cornell University Press, 960p.

Amaral-Calvão, A.M.R. do \& M. Maia-Herzog. 2003. Coleção de simuliídeos (Diptera - Simuliidae) de Adolpho Lutz, sua história e importância. História, Ciência e Saúde - Manguinhos 10: 259-271.

Bremer, K. 1994. Branch support and tree stability. Cladistics 10: 295-304.

Cerqueira, N.L. 1967. Simuliidae da Amazônia. III. Sobre o gênero "Simulium" Latreille, 1982 (Diptera, Nematocera). Atas do Simpósio sôbre a Biota Amazônica 5 (Zoologia): 127-139.

Coscarón S. 1981. Fauna de agua dulce de la Republica Argentina 38. Insecta, Diptera, Simuliidae, Fasciculo 1. Buenos Aires, Fundación para la Educación, la Ciencia y la Cultura, 105p.

Coscarón S. 1991. Fauna de agua dulce de la Republica Argentina 38. Insecta, Diptera, Simuliidae, Fasciculo 2. Buenos Aires, Fundación para la Educación, la Ciencia y la Cultura, 304p.

Coscarón, S.; Cerqueira, R.L. de; Schumaker, T.T.S. \& V. La Salvia FILHo. 1992. Nuevos datos sobre distribuición de simulideos de Brasil y descripción de Simulium (Coscaroniellum) cerradense sp. nov. (Diptera, Simuliidae). Revista Brasileira de Entomologia 36: 111-119.

Coscarón, S. \& C.L. CosCarón-ARIas. 2002. Araucnephia iberaensis n. sp., a Neotropical Black Fly with a Peculiar Distribution (DipteraSimuliidae). Memórias do Instituto Oswaldo Cruz 97: 81-87.

Coscarón S. \& C.L. Coscarón-Arias. 2007. Neotropical Simuliidae (Diptera: Insecta). In: J. Adis; J.R. Arias; G. Rueda-Delgado \& K.M. WANTZEN (Eds). Aquatic Biodiversity in Latin America (ABLA). Sofia-Moscow, Pensoft, vol. 3, 685p.

Coscarón S.; Coscarón-Arias, C.L. \& N. Papavero. 2008. Catalogue of Neotropical Diptera. Simuliidae. Neotropical Diptera 2: $1-90$.

Coscarón, S. \& D.R. Miranda-Esquivel. 1998. Pedrowygomyia, a new Neotropical genus of Prosimuliini (Diptera: Simuliidae): Gigantodax s. lat. split into two genera. Entomologica Scandinavica 29: 161-167.

Crosskey, R.W. \& T.M. Howard. 1997. A new taxonomic and geographical inventory of world blackflies (Diptera: Simuliidae). London, The Natural History Museum, 144p.

Crosskey, R.W. \& T.M. Howard. 2004. A revised taxonomic and geographical inventory of world blackflies (Diptera: Simuliidae). London, The Natural History Museum. Available online at: http://www.nhm.ac.uk/researchcuration/projects/blackflies/ [Accessed: 14/X/2007].

Currie, D.C. \& D. Grimaldi. 2000. A new black fly (Diptera: Simuliidae) genus from mid Cretaceous (Turonian) amber of New Jersey, p. 473-485. In: D. Grimaldi (Ed.). Studies on fossil amber, with particular reference to the Cretaceous of New Jersey. Leiden, Backhuys Publishers, 504p.

D’Andretta JR, C. \& M.A. Vulcano. 1947. As espécies neotropicais da família Simuliidae Schiner (Diptera Nematocera). II. Lutzsimulium cruzi n. gen. e n. sp. e nova concepção da nervação das asas dos simulídeos. Memórias do Instituto Oswaldo Cruz 44: 401-412.

D'Andretta JR, C. \& M.A. Vulcano. 1948. Espécies neotropicais da família Simuliidae Schiner (Diptera Nematocera). IV. Lutzsimulium cruzi Andr. \& Andr. 1946: descrição do alótipo macho e da larva. Arquivos de Zoologia do Estado de São Paulo 5: 637-647.

Dellome Filho, J. 1991. Simuliofauna do Rio Marumbi (Morretes, PR, Brasil). I. Coleta e Criação; dados metereológicos e físico-químicos do criadouro; adultos (Diptera, Simuliidae). Acta Biológica Paranaense 20: 145-156.

ERIKSson, T. 2001. AutoDecay, version 5.0. Bergius Foundation, Royal Swedish Academy of Sciences, Stockholm. Available online at: http://www.bergianska.se/soft [Accessed: 8/VI/2008).

Evans, C.L. \& P.H. AdLER. 2000. Microsculpture and phylogenetic significance of the spermatheca of black flies (Diptera: Simuliidae). Canadian Journal of Zoology 78: 1468-1482.

FArChILD, G.B. 1940. Notes on the Simuliidae of Panama (Dipt., Nematocera). Annals of Entomological Society of America 33: 701-719. 
Felsenstein, J. 1985. Confidence limits on phylogenies: an approach using the bootstrap. Evolution 39: 783-791.

Figueiró, R.; C.J.P.C. Araújo-Coutinho; L.H. Gil-Azevedo; E.S. NaScimento \& R.F. Monteiro. 2006. Spatial and Temporal Distribution of Blackflies (Diptera: Simuliidae) in the Itatiaia National Park, Brazil. Neotropical Entomology 35: 542-550.

FiтcH, W.N. 1971. Toward defining the course of evolution: minimum change for a specified tree topology. Systematic Zoology 20: 406-416.

Floch, H. \& E. Abonnenc. 1946. Simulides de la Guyane Française I - S. guianense Wise, 1911, S. rorotaense n. sp., S. maroniense n. sp. Publication Institute Pasteur, Guyane Française et Terre de l'Infini 136: 1-20.

Forattini, O.P.; E.X. Rabello \& M.D. Cotrim. 1971. Catálogo das coleções entomológicas da Faculdade de Saúde Pública da Universidade de São Paulo ( $1^{\text {a }}$ série). Revista de Saúde Pública, São Paulo 5: 301-366.

Gil-Azevedo, L.H.; R. Figueiró \& M. Maia-Herzog. 2005A. Simulium (Psaroniocompsa) stellatum (Diptera: Simuliidae), a new black fly from a high mountain range in southeastern Brazil. Zootaxa 922: 1-12.

Gil-Azevedo, L.H.; N. Ferreira Jr \& M. Maia-Herzog. 2005в. Chave de identificação de pupas de Simuliidae (Diptera) do Sudeste do Brasil. Revista Brasileira de Zoologia 22: 742-752.

Gil-Azevedo, L.H. \& M. Maia-Herzog. 2007. Preliminary Considerations on Phylogeny of Simuliidae Genera from Southern Hemisphere (Insecta-Diptera). Zootaxa 1643: 39-68.

Gil-Azevedo, L.H. \& M. Maia-Herzog. 2010 (2009). Espécies de Simuliidae registradas no Estado do Rio de Janeiro, Brasil. Arquivos do Museu Nacional 67: 349-354.

Goloboff, P.A. 1993. NONA, version. 2.0. Published by the author, Tucumán, Argentina. Available online at: http:// www.cladistics.com [Accessed: 29/VII/2008].

International Commission on Zoological Nomenclature. 1999. International code of zoological nomenclature. Fourth Edition. International Trust for Zoological Nomenclature, London. Available online at: http://www.iczn.org/iczn/index.jsp [Accessed: 17/III/2009].

KNAB, F. 1911. Dr. A. Lutz's studies of Brazilian Simuliidae. Proceedings of the Entomological Society of Washington 13: 172-179.

Lacey, L.A. 1981. Simulídeos antropofílicos no Parque Nacional da Amazônia (Tapajós), Brasil, com referência aos efeitos no homem. Bulletin of Pan American Health Organization 90: 326-337.

Lacey, L.A. \& J.D. Charlwood. 1980. On the biting activities of some anthropophilic Amazonian Simuliidae (Diptera). Bulletin of Entomological Research 70: 495-509.

Landeiro, V.L.; M. Pepinelli \& N. Hamada. 2009. Species Richness and Distribution of Blackfl ies (Diptera: Simuliidae) in the Chapada Diamantina Region, Bahia, Brazil. Neotropical Entomology 38: 332-339.

Lane, J. \& C.E. Porto. 1939. Simulídeos da Região Neotrópica.
O gênero Eusimulium. Boletim Biológico (N.S.) 4: 168-176. LANE, J. \& M.A. Vulcano. 1943. A armadura bucal dos simulídeos e seu valor taxonômico (Diptera, Simuliidae). Revista de Entomologia 14: 430-440.

Lozovei, A.L.; F. Petry; L.G. Santos Neto; M.E. Ferraz. 2004. Levantamento das espécies de Simulium (Diptera, Simuliidae), Riacho dos Padres, município de Almirante Tamandaré, Paraná, Brasil. Revista Brasileira de Entomologia 48: 9194.

LuTZ, A. 1909. Contribuição para o conhecimento das espécies brasileiras do gênero Simulium. Memórias do Instituto Oswaldo Cruz 1: 124-146.

LuTZ, A. 1910. Segunda contribuição para o conhecimento das espécies brasileiras do gênero Simulium. Memórias do Instituto Oswaldo Cruz 2: 213-267.

LuTz, A. 1922. Zoologia medica - Nematoceros hematóphagos não pertencendo aos culicídeos. A Folha Médica, Rio de Janeiro 3: 89-92.

Miranda-Esquivel, D.R. \& S. Coscarón. 2001. Cladistic analysis of Simulium (Trichodagmia) and Simulium (Thyrsopelma) (Diptera: Simuliidae). Zoological Journal of the Linnean Society 132: 429-439.

Moulton, J.K. 2000. Molecular sequence data resolves basal divergences within Simuliidae (Diptera). Systematic Entomology 25: 95-113.

Moulton, J.K. 2002. Can the current molecular arsenal adequately track rapid divergence events within Simuliidae (Diptera)? Molecular Phylogenetics and Evolution 27: 4557.

Nerva, A. \& B. Penna. 1916. Viajem científica pelo norte da Bahia, sudoeste de Pernambuco, sul do Piauhí e de norte a sul de Goiaz. Memórias do Instituto Oswaldo Cruz 8: 1-224.

NIXON, K.C. 2002. WinClada, version 1.00.08. Ithaca, Published by the author. Available online at: http://www.cladistics.com [Accessed: 8/I/2009.

Pepinelli, M.; S. Trivinho-Strixino \& N. Hamada. 2003. New records of Simuliidae (Diptera, Nematocera) in the State of São Paulo, Brazil. Revista Brasileira de Entomologia 47: 653-655.

Pepinelli, M.; N. Hamada \& S. Trivinho-Strixino. 2006. Larval Description of Simulium (Notolepria) cuasiexiguum and Simulium (Chirostilbia) obesum and New Records of Black Fly Species (Diptera: Simuliidae) in the States of São Paulo and Minas Gerais, Brazil. Neotropical Entomology 35: 698-704.

PinTo, C. 1930. Arthrópodes parasitos e transmissores de doenças, 2, p. 397-845. In: Tratado de Parasitologia. vol. 4.

PINTo, C. 1932. Simuliidae da América Central e do Sul (Diptera). $7^{\text {a }}$ Reunión de la Sociedad Argentina de Patologia de la Región Norte 60: 661-763.

Pinto-Sanchéz, N.R.; D.R. Miranda-Esquivel \& P. Munoz de Hoyos. 2005. Phylogenetic analysis of Gigantodax. Insect Systematics and Evolution 36: 219-239.

Py-Daniel, V. 1979. Algumas considerações sobre Simuliidae (Diptera: Nematocera). Acta Amazonica 9: 783-786. 
Py-Daniel, V. 1981. Algumas considerações sobre Simuliidae (Diptera - Nematocera) - II. Acta Amazonica 11: 171-181. Py-Daniel, V. 1982. Prosimuliini (Diptera: Simuliidae) Neotropical. 1 - Kempfsimulium V. Py-Daniel \& J.A. Nunes de Mello n. gen.; K. simplicicolor (Lutz, 1910) n. comb.; Lutzsimulium flavopubescens (Lutz, 1910) n. comb.; Mayacnephia muzquicensis (Díaz Nájera, 1971) n. comb. Amazoniana 7: 293-333.

Py-Daniel, V. \& R.T.M. Sampaio. 1994. Jalacingomyia gen.n. (Culicomorpha); a ressurreição de Gymnopaidinae; a eliminação do nivel tribal; apresentação de novos critérios e a redescrição dos estágios larval e pupal de Simulium colombaschense (Fabricius, 1787) (Diptera: Simuliidae). Memorias del CAICET 4: 101-148.

Py-Daniel, V. \& R.T.M. Sampaio. 1995. Gêneros e espécies de Simuliidae (Diptera: Culicomorpha) assinalados para o Brasil até 1995. Entomologia y Vectores 2: 117-121.

RubTsov, P.A. 1940. Moshki (Sem. Simuliidae) in Zoologicheskii Institut Akademii Nauk SSSR: Fauna SSSR (Novaia Seria 23). Nasekomye Dvukrylye 6: 1-533.

Shelley, A.J.; L.M. Hernández; M. Maia-Herzog; AP.A. Luna-Dias \& P.R. Garritano. 2010. The blackflies (Diptera: Simuliidae) of Brazil. In: J.R. Arias; S. Golovatch; K.M. Wantzen \& E. Domínguez (Eds). Aquatic Biodiversity in Latin America (ABLA). Sofia-Moscow, Pensoft, vol. 6, 821p.

Shelley, A.J.; C.A. Lowry; M. Maia-Herzog; A.P.A. Luna Dias \& M.A.P. Moraes. 1997. Biosystematic studies on the Simuliidae (Diptera) of the Amazonia onchocerciasis focus of Brazil. Bulletin of the Natural History Museum (Entomology series) 66: 1-121.

Shelley, A.J.; M. Maia-Herzog; C.A. Lowry; A.P.A. Luna Dias; P.R. Garritano; A. Shelley; M. Camargo \& H.G. Carter. 2000. The Simuliidae (Diptera) of the secondary onchocerciasis focus at Minaçu in central Brazil. Bulletin of The Natural History Museum (Entomology series) 69: 171-221.

SMART, J. 1945. The classification of the Simuliidae (Diptera). The Transactions of the Royal Entomological Society of London 95: 463-528.

STONE, A. 1963. An annoted list of genus-group names in the family Simuliidae (Diptera). U.S. Deptament of Agriculture Technical Bulletin 1284: 1-28.

Strieder, M.N. 2002. Diversidade e distribuição de Simuliidae (Diptera, Nematocera) no gradiente longitudinal da Bacia do Rio Maquiné, RS, Brasil. Biociências 10: 127-137.

Strieder, M.N. 2004. Espécies de simulídeos (Diptera, Nematocera, Simuliidae) no Rio Grande do Sul, Brasil: distribuição geográfica. Entomologia y Vectores 11: 113-143.

Strieder, M.N.; J.E. dos Santos Jr \& A.M.O. Pês. 2002. Diversidade e Distribuição de Simuliidae (Diptera, Nematocera) no gradiente longitudinal da Bacia do Rio dos Sinos, no Rio Grande do Sul, Brasil. Entomologia y Vectores 9: 527-540.

Strieder, M.N.; J.E. dos Santos JR \& E.M. Vieira. 2006. Distribuição, abundância e diversidade de Simuliidae (Diptera) em uma bacia hidrográfica impactada no sul do Brasil. Revista Brasileira de Entomologia 50: 119-124.

Stuart, A.E. \& F.F. Hunter. 1998. End-products of behaviour versus behavioural characters: a phylogenetic investigation of pupal cocoon construction and form in some North American black flies (Diptera: Simuliidae). Systematic Entomology 23: 387-398.

Surcouf, J.M.R. \& R. Gonzalez-Rincones. 1911. Simuliidae, p. 274295. Essai sur les diptères vulnerants du Venezuela. Matériaux pour à l'étude des diptères piqueurs et suceur de l'Amérique intertropicale. Paris, A. Maloine Éditeur.

Swofford, D.L. 1998. PAUP*. Phylogenetic Analysis Using Parsimony (*and Other Methods), version 4. Sunderland, Sinauer Associates.

VARgas, L. 1945. Simulidos del Nuevo Mundo. Mexico, Instituto de Salubridad y Enfermedades Tropicales.

Vulcano, M.A. 1962. Simulídeos da Serra da Bocaina: observações bionômicas, revalidação de Simulium brevifurcatum Lutz e descrição de uma espécie nova, $S$. ana-mariae (Diptera, Simuliidae). Papéis Avulsos do Departamento de Zoologia, Secretaria de Agricultura 15: 239-272.

Vulcano, M.A. 1967. A catalogue of the Diptera of the Americas south of the United States. 16. Simuliidae. São Paulo, Departamento de Zoologia, Secretaria da Agricultura.

Vulcano, M.A. 1977. Simuliidae, p. 285-293. In: S.H. Hurlbert (Ed.). Biota acuatica de Sudamérica austral. San Diego, San Diego State University.

Vulcano, M.A. 1981. Simuliidae, p. 275-285. In: S.H. Hurlbert; G. Rodríquez \& N.D. Dos SANTos (Eds). Aquatic biota of tropical South America: being a compilation of taxonomic bibliographies for the fauna and flora of inland waters of the tropical portion of South America. San Diego, San Diego State University.

Vulcano, M.A. \& C. D'Andretta JR. 1952. Espécies neotropicais da família Simuliidae (Diptera Nematocera). VII Redescrição de Lutzsimulium pernigrum (Lutz, 1910), n.comb. e considerações sobre o gênero. Papéis Avulsos do Departamento de Zoologia 10: 307-323.

WiLKINSON, M. 1995. A comparison of two methods of character reconstruction. Cladistics 11: 297-308.

Wygodzinsky, P. \& S. CoscARón. 1973. A review of Mesoamerican and South American black flies of the tribe Prosimuliini (Simuliinae, Simuliidae). Bulletin of the American Museum of Natural History 151: 133-199.

Submitted: 28.VII.2009; Accepted: 11.VII.2010.

Editorial responsibility: Antonio C. Marques 
Appendix 1. List of material examined of the outgroup.

Araucnephia iberaensis: MLP: 3 f\# (pinned) [Argentina, Corrientes e/Itujanigo y Galarza (1-2/VI/2000, S. Coscarón coll.)]. 1 f\# (pinned)

[Argentina, $4^{\circ}$ arroyo hacia Galarza (13/VIII/2000, S. Coscarón coll.)]. $2 \mathrm{f \#} \mathrm{and} 1 \mathrm{m \#}$ with pupal pelts and 1 larva (slide) [Argentina, Corrientes, Ao. 8 km N. de Galarza (01/VI/1980, S. Coscarón coll. - paratypes)]. 1 m\# with pupal pelt (slide) [Argentina, Corrientes, Galarza (02/VI/2000, S. Coscarón coll. - paratypes)]. 1 m\# with pupal pelt (slide), 5 pupae and 5 larvae (spirit) [Argentina, Corrientes, entre Itacua y Galarza (13/VIII/2000, S. Coscarón coll. - paratypes)]. 2 larvae (slide) [Argentina, Corrientes, 2 km de Itacua (01/VI/2000, Coscarón coll.)]. LSO-IOC: 1 pupa and 2 larvae (spirit) [Argentina, Corrientes, Galarza (01/VI/2000, S. Coscarón coll.)].

Araucnephia montana: MLP: 1 f\# (pinned) [Base Cuesta 2, Calligury Valoso (20/IX/1969, J. Solervicens coll.)]. 1 m\# with pupal pelt and 2 larvae (slide) [Chile, Santiago (02/X/1972, S. Coscarón coll.)]. 1 pupa (slide) [Chile, Santiago (04/X/1972, S. Coscarón coll.)]. 5 pupae and 5 larvae (spirit) [Chile, Santiago (04/X/1972, S. Coscarón leg.)]. LSO-IOC: 1 f\# (slide) [027 - Chile, Cordillera, Río Clarillo]. 1 f\# with pupal pelt (pinned) [034 - Chile, El Arrayau]. 1 f\# (pinned) [039 - Chile, Cordillera, Río Clarillo].

Gigantodax brophyi: MLP: 1 f\# (pinned) [Argentina, Neuquén, ruta 40 (21/XI/1970, S. Coscarón coll.)]. 2 f\# (pinned) [Argentina, Neuquén, Chapelco (24/III/1982, 11/I/1983, Gentili coll.)]. 1 m\# (pinned) [Argentina, Río Negro, Bariloche (21/IX/1984, S. Coscarón coll.)]. 1 f\# and $1 \mathrm{m \#}$ (slide) [Chile, Magallanes, Isla Deceit (27/XI a 03/XII/1983, D. Lanfranco coll.)]. 3 pupae (slide) [Argentina, Tierra del Fuego, Ushuaia (20/28/I/1960, P. Wygodzinky \& S. Coscarón coll.)]. 1 pupae (slide) [Argentina, Chubut, Río Pico (17/II/1961)]. 3 pupae (spirit) [Argentina, Río Negro, Ao. s/Lago Mascardi (03/II/1984)]. 1 larva (slide) [Argentina, Santa Cruz, Peninsula Magallanes (20/I/1993, S. Coscarón coll.)]. 1 larva (slide) [Argentina, Tierra del Fuego, Ushuaia (02/I/1960, P. Wygodzinsky coll.)]. 6 larvae (spirit) [Argentina, Tierra del Fuego, Chorrillos (08/XII/1983, S. Coscarón coll.)].

Helodon alpestris: MLP: $1 \mathrm{m \#}$ with pupal pelt and 1 larva (slide) [Russia, Siberia, 79A MP 266]. 5 pupae and 5 larvae (spirit) [?]. ROM: 20 pupae and 20 larvae [Canada, B.C., Cassiar Mts. 10 km S. Cassiar Jct on Cassiar Hwy. (01/IX/1982, D.C. Currie)].

Paracnephia tonnoiri: BMNH: 1 f\# (pinned) [Australia (11/VIII/1951, Q. Denwich coll.)]. MLP: 1 pupa and 1 larva (slide), 1 m\# and 4 larvae (spirit) [Australia].

Paraustrosimulium anthracinum: MLP: 1 f\# and 1 m\# (pinned) [Chile, Magallanes, Islã Deceit (22/XI a 05/XII/1982, D. Lanfranco coll.)]. 1 m\# (pinned) [Argentina, Tierra del Fuego, Ushuaia (22/I/1960, S. Coscarón, coll.)]. 1 f\# (pinned) [Chile, Puente Mafil, sobre Panamer. (21/XI/1992, S. Coscarón coll.)]. 1 f\# (pinned) [Chile, Huillinco (07/II/1960, S. Coscarón coll.)]. 1 f\# and 1 m\# with pupal pelt (slide) [Chile, Chiloe, e/Huillingo y Chonchi (30/XI/1992, S. Coscarón coll.)]. 1 f\# with pupal pelt (slide) [Chile, Freire s/Panamericana (23/XI/ 1992, S. Coscarón coll.)]. 1 larva (slide) [Chile, Freire, Puente Mafil (24/X/1992, S. Coscarón coll.)]. 2 f\# with pupal pelt and 1 larva (slide) [Argentina, Isla de Los Estados (XI/1965, Bachmann coll.)]. 5 pupae and 5 larvae (spirit) [Argentina, Río Negro, Ao. Próx. Playa Serena (18)]. LSO: 2 pupae and 3 larvae (spirit) [Chile, Chiloe, Pte. Mafil (24/XI/1992, S. Coscarón coll.)].

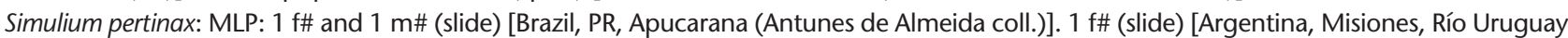
(10/VI/1971, S. Coscarón coll.)]. 1 pupa (slide) [Brazil, SC, Gruesas (?)]. 1 larva (slide) [Argentina, Misiones, Ao. Yacuy Chico (01/VII/1971, S. Coscarón coll.)]. 1 m\# with pupal pelt (pinned) [Brazil, SC, córrego Pindotiba (05/XI/1981, S. Coscarón coll.)]. 1 f\# with pupal pelt (pinned) [Brazil, SC, Florianópolis (04/XI/1981, S. Coscarón coll.)]. 1 f\# with pupal pelt (pinned) [Argentina, Misiones, camino a San Pedro (18/X/1974, S. Coscarón coll.)]. LSO-ICO: 2 larvae (slide) [Brazil, RJ, Angra dos Reis (24/V/2002, J. Nessimian coll.)]. 1 f\# and 2 m\# with pupal pelts (pinned) [Brazil, R], Rio de Janeiro (18/IX/1984, M. Herzog \& R. Malaguti coll.)]. $1 \mathrm{f \#} \mathrm{with} \mathrm{pupal} \mathrm{pelt} \mathrm{(pinned)} \mathrm{[Brazil,} \mathrm{RJ,} \mathrm{Rio} \mathrm{de}$ Janeiro (18/VI/1984, R. Malaguti \& M. Castro coll.)]. 1 m\# (pinned) [Brazil, RJ, Rio de Janeiro (13/VIII/1984, M. Herzog \& R. Malaguti coll.)].

Appendix 2. Character state matrix for the cladistic analyses of Lutzsimulium from and outgroup taxa. - Codes for inapplicable data, ? for unavailable, a for $(0+1)$.

\begin{tabular}{|c|c|c|c|c|c|c|}
\hline & & 1 & 2 & 3 & 4 & 5 \\
\hline & 123456789 & 0123456789 & 0123456789 & 0123456789 & 0123456789 & 0123 \\
\hline Helodon alpestris & $000-00000$ & $0000000-00$ & a 101001101 & 0001011001 & $011000--0-$ & -011 \\
\hline Araucnephia montana & 100000001 & $0000100-00$ & 0101011101 & 0001 a 11001 & $001000010-$ & -011 \\
\hline Araucnephia iberaensis & 100000011 & $0000100-01$ & $01010010 ? 0$ & 0001110001 & $001100010-$ & -011 \\
\hline Gigantodax brophyi & 000102000 & $0100000-10$ & $010 ? 000101$ & 1001 a 11111 & 001000020 - & -010 \\
\hline Paracnephia tonnoiri & 000102000 & $0100010-11$ & $00 ? ? 000-0-$ & 1001111111 & $001010020-$ & -010 \\
\hline Simulium pertinax & $11-000111$ & $1100100-02$ & $-00 ? 001101$ & $0020-00000$ & 1010111110 & 0000 \\
\hline Paraustrosimulium anthracinı & $n 01-000100$ & $0000110-00$ & $11 ? 1001101$ & $1-10200000$ & $100111010-$ & -001 \\
\hline Lutzsimulium hirticosta & 000101111 & 1010121011 & 100 & 0101110001 & 0101111111 & 0111 \\
\hline Lutzsimulium pernigrum & 100110111 & 1010121011 & a 0011 & 0101110 & 0111111112 & 1010 \\
\hline Lutzsimulium flavopubescens & 000110111 & 1010121011 & 0001101010 & 0101110001 & 0111111112 & 1010 \\
\hline Lutzsimulium simplicicolor & 101112111 & 1001121111 & 0110011000 & 0101111001 & 0011111011 & 0010 \\
\hline
\end{tabular}

ZOOLOGIA 27 (5): 761-788, October, 2010 